\title{
THE IMPACT OF THE SOUTH AFRICAN LAW OF SUCCESSION AND ADMINISTRATION OF ESTATES ON SOUTH AFRICAN MUSLIMS
}

\author{
Muneer Abduroaf ${ }^{1}$
}

\begin{abstract}
Muslims have been living in South Africa for over 300 years. There are currently over 750000 Muslims living in South Africa. These Muslims constitute a minority religious group in a nonMuslim country. There has (to date) been no legislation enacted by the South African parliament that gives effect to Islamic law provisions. This paper analyses the South African law of succession and administration of estates and looks at how it applies to the estates of deceased Muslims who lived in South Africa prior to dying. It looks at the possibility of using existing South African law provisions in order to apply the Islamic law of succession within the South African context. It concludes with an overall analysis and a recommendation.
\end{abstract}

Keywords: Islamic law, South African law, testate succession, intestate succession, Constitutional law

\section{INTRODUCTION}

South Africa was subject to approximately 350 years of colonialism. It was during this time that apartheid dominated the South African legal system. The

Lecturer, Department of Criminal Justice and Procedure, Faculty of Law, University of the Western Cape, Cape Town, 7535, South Africa, mabduroaf@ uwc.ac.za 
Cape was colonised by Dutch settlers on 6 April 1652. It remained under Dutch rule until 1795 when it fell to British occupation. It reverted back to Dutch rule in 1803. It then later reverted back to British occupation in 1806. Many of the Dutch settlers then moved north in order to avoid living under British rule. ${ }^{2}$ Apartheid was introduced into South Africa in 1948 and South Africa became a Republic on 31 May 1961..$^{3}$ The above-mentioned situation led to South Africa reflecting the values of the colonial and apartheid rules. South Africa currently has a mixed legal system. The sources of South African law include customary law, case law, and legislation. ${ }^{4}$ The South African law of succession and administration of deceased estates in its current form incorporates all of these sources. Muslims have been living in South Africa for over 300 years. ${ }^{5}$ There are currently over 750000 Muslims living in South Africa. ${ }^{6}$ They constitute a minority religious group in a non-Muslim country. There has (to date) been no legislation enacted by the South African parliament that gives effect to Islamic law provisions.

This paper looks at the South African law of succession and administration of estates in general terms. It looks at how these South African law provisions apply to the estates of deceased Muslims who lived in South Africa prior to dying. It looks at the possibility of using existing South African law provisions governing wills in order to apply the Islamic law of testate and intestate succession within the South African context. Possible constitutional challenges to discriminatory provisions found within the South African law of succession are pointed out where relevant. An overview of the South African law of

2 See African Charter on Human and Peoples' Rights - Chapter 2 'Introduction to the South African Legal System,' http://www.justice.gov.za/policy/african $\% 20$ charter/afr-charter02.html, accessed on 14 October 2017. See also Du Toit F., 'Roman-Dutch Law in Modern South African Succession Law,' Ars Aequi (2014): 278.

3 See South African History Online, 'A History of Apartheid in South Africa,' http:// www.sahistory.org.za/article/history-apartheid-south-africa, accessed 2 January 2018.

4 See Rautenbach C, 'Introduction,' in The Law of Succession in South Africa, ed. Juanita J. \& Rautenbach C. (Cape Town: Oxford, 2009), 1-3.

5 The first recorded Muslim arrived in South Africa in 1654. See Mahida EM, History of Muslims in South Africa: A Chronology (Durban: Arabic Study Circle, 1993), 1.

6 Statistics South Africa, 'Census 2001 Primary Tables South Africa 96 and 2001 Compared,' http://www.statssa.gov.za/census01/html/RSAPrimary.pdf, accessed on 3 January 2015. It should be noted that religion has not formed part of the published censuses since 2001. 
The Impact of the South African Law of Succession and Administration of Estates on South African Muslims

succession and administration of estates is looked at by way of introduction. This is followed by looking at the conditions to be met before administering an estate. The claims against the gross estate of a deceased person are then looked at. This is followed by a detailed analysis of liability claims, testate succession claims, and then intestate succession claims against the deceased estate. The position of females within the South African law of intestate succession is then looked at. The findings of this paper are then briefly examined and concluding remarks are made.

\section{AN OVERVIEW OF THE SOUTH AFRICAN LAW OF SUCCESSION AND ADMINISTRATION OF ESTATES}

There are two branches of succession law within the South African context. These branches are referred to hereafter as the common law and the customary law. ${ }^{7}$ There are two versions of the customary law. These versions are referred to as the living and the official versions. The living version of customary law refers to the actual customs and practices of the indigenous community. ${ }^{8}$ The official version of customary law refers to the law that is applied by the court and other state institutions. ${ }^{9}$ The laws referred to in this paper are in terms of the official version except where stated otherwise. ${ }^{10}$ The rule of male primogeniture was originally found within the official version of customary law. An example of how the rule applies could be seen where $\mathrm{X}$ dies, leaving behind a son and a daughter as the only relatives. The son would inherit to the exclusion of the daughter. The rule was found to be unconstitutional in Bhe and Others $v$ Khayelitsha Magistrate and Others (Bhe). ${ }^{11}$ It was declared invalid to the extent that it excludes or hinders women and extramarital children from inheriting property. ${ }^{12}$ The judgment was decided by the Constitutional Court on 15 October 2004. The Bhe judgment led to the enactment of the Reform of Customary Law of Succession and Regulation of Related Matters Act 11 of

7 Paleker M, 'Intestate Succession,' in The Law of Succession in South Africa, ed. Juanita J. \& Rautenbach C. (Cape Town: Oxford, 2009), 17.

8 Himonga C \& Nhlapo T (eds), African Customary Law in South Africa - Post Apartheid and Living Law Perspectives (Cape Town: Oxford, 2015), 27.

9 Himonga C \& Nhlapo T (eds), African Customary Law in South Africa - Post Apartheid and Living Law Perspectives, 33.

10 Paleker M, 'Intestate Succession,' 17-18.

11 Bhe and Others $v$ Magistrate Khayelitsha and Others 2005 (1) SA 580 (CC) 8084.

12 Bhe and Others $v$ Magistrate Khayelitsha and Others 2005 (1) SA 580 (CC) 8084. 
2009. ${ }^{13}$ The Act applies only to persons who is subject to customary law. ${ }^{14}$ The Act further states that there is nothing preventing persons subject to customary law from disposing assets in terms of a will. ${ }^{15}$ This is an innovation in terms of customary law as freedom of testation was initially restricted to a large extent. ${ }^{16}$

A testator or testatrix can technically bequeath his or her estate in terms of the rule of primogeniture. There is no clear answer as to whether such a provision in a will would pass constitutional muster. ${ }^{17} \mathrm{~A}$ similar question could be asked concerning the Islamic law of intestate succession. A testator or testatrix can also technically bequeath his or her estate in terms of the Islamic law of succession. The current position in South Africa is that the common and the customary laws of succession are subject to almost identical laws with minor variations. ${ }^{18}$ Some of these variations are compared to each other where relevant. The provisions referred to in this paper are in terms of the common law and customary law except where stated otherwise.

13 Reform of Customary Law of Succession and Regulation of Related Matters Act 11 of 2009.

14 Section 2(1) of the Reform of Customary Law of Succession and Regulation of Related Matters Act 11 of 2009 where it states that 'The estate of any person who is subject to customary law who dies after the commencement of the Act and whose estate does not devolve in terms of that person's will, must devolve in accordance with the law of intestate succession as regulated by the Intestate Succession Act, subject to subsection (2).' It should be noted that subsection 2 is where the customary law of succession is found. It should also be noted that s 1 of the Reform of Customary Law of Succession and Regulation of Related Matters Act 11 of 2009 defines customary law as 'as the customs and practices observed among the indigenous African people of South Africa which form part of the culture of those people.'

15 Section 4(3) of the Reform of Customary Law of Succession and Regulation of Related Matters Act 11 of 2009 where it states that '[n]othing in this section is to be construed as preventing any person subject to customary law, other than the woman referred to in subsection (1), from disposing assets in terms of a will.'

16 Rautenbach C, 'A Few Comments on the (Possible) Revival of the Customary Law Rule of Male Primogeniture: Can the Common-Law Principle of Freedom of Testation come to its Rescue?' in South African Law of Succession and Trusts: The Past Meeting the Present and Thoughts for the Future, ed. De Waal N \& Paleker M (Claremont: Juta, 2014), 152.

17 For a discussion on this issue, see Rautenbach C, 'A Few Comments on the (Possible) Revival of the Customary Law Rule of Male Primogeniture: Can the Common-Law Principle of Freedom of Testation come to its Rescue?' 152-157.

18 See Reform of the Customary Law of Succession of Related Matters Act 11 of 2009. 
The Impact of the South African Law of Succession and Administration of Estates on South African Muslims

\section{CONDITIONS TO BE MET BEFORE ADMINISTERING AN ESTATE}

There are certain conditions that must be met before the estate of a person can be deemed a deceased estate and thus subject to liquidation and distribution in terms of the law of succession and administration of estates. ${ }^{19}$ The person in question must have died or been declared dead by a court of law. It is at this moment that the estate falls open. ${ }^{20}$ It is also at this moment that the rights of beneficiaries to the estate become vested..$^{21}$ The moment is referred to hereafter as "dies cedit". The exception to this rule would be where a court pronounces a presumption of death and orders that the estate must be divided. ${ }^{22}$ The beneficiaries must be alive at the time of "dies cedit". The exception to this would be where a testator or testatrix made provision in a will for benefiting persons who are born later, or where statutory substitution finds application. ${ }^{23}$ A beneficiary that was conceived but not yet born at the time of "dies cedit" would inherit the benefit only if subsequently born alive. ${ }^{24}$ Persons who die simultaneously are not able to mutually inherit from one another. The courts would accept that they died simultaneously unless the contrary is proven. ${ }^{25} \mathrm{An}$ example of this would be where a husband and wife die in a car accident and the moment of death of either party cannot be confirmed. ${ }^{26}$

The term 'beneficiaries' is used in this paper to refer to those persons who are appointed as such in terms of a will (testate beneficiaries) and/or those persons who are related to the deceased in terms of one or more intestate succession ties (intestate beneficiaries). The moment at which a vested right becomes enforceable is referred to hereafter as "dies venit". ${ }^{27}$ It should be

\footnotetext{
19 Rautenbach C, 'Introduction,' 12-16.

20 This moment is also referred to as delatio. De Waal MJ \& Schoeman-Malan MC, Law of Succession (Cape Town: Juta, 2015), 9.

21 This refers to those beneficiaries who are neither totally excluded nor disqualified.

22 De Waal MJ \& Schoeman-Malan, Law of Succession, 11-12; Rautenbach C, 'Introduction,' 12-16.

23 See De Waal MJ \& Schoeman-Malan, Law of Succession, 11-12; Rautenbach C, 'Introduction,' 12-16.

24 See De Waal MJ \& Schoeman-Malan, Law of Succession, 11-12; Rautenbach C, 'Introduction,' 12-16.

25 De Waal MJ \& Schoeman-Malan, Law of Succession, 12.

26 It should be noted that Islamic law has a similar position in this regard and includes a presumption of simultaneous death.

27 De Waal MJ \& Schoeman-Malan, Law of Succession, 9.
} 
noted that the two moments could coincide but that "dies cedit" can never precede "dies venit". ${ }^{28}$ An example of an instance where "dies cedit" precedes "dies venit" would be where X bequeaths $1 / 3$ of his testate estate in favour of his full brother (testate beneficiary) subject to the condition that he passes all his final year law modules with distinctions. "Dies cedit" would take place at the moment of the deceased having died but "dies venit" would take place the moment the full brother obtains distinctions for all his final year modules. "Dies cedit" and "dies venit" would always coincide in terms of the law of intestate succession (intestate beneficiaries). The examples referred to hereafter are where "dies cedit" and "dies venit" coincide unless expressly stated otherwise. ${ }^{29}$

\section{CLAIMS AGAINST THE GROSS ESTATE}

The term 'estate' is used in this paper to refer to the assets and liabilities of a deceased person. If the assets in an estate exceed the liabilities then it would be deemed solvent. If the liabilities in an estate exceed the assets it would be deemed insolvent. ${ }^{30}$ The term 'gross estate' is used in this paper to refer the sum of assets within an estate. The term 'net estate' is used in this paper to refer to the remainder of the gross estate, after all liability claims have been deducted. The net estate is further divided into the 'testate estate' and 'intestate estate'. The testate estate is distributed in terms of the law of testate succession and the intestate estate is distributed in terms of the law of intestate succession. It is quite interesting to note that the proceeds of a pension fund do not form part of the assets in the estate of the deceased member. The laws of testate and intestate succession therefore do not apply to it. ${ }^{31}$ It should be noted that there is a contemporary opinion within Islamic law stating that the proceeds of a pension fund is not subject to the Islamic law of intestate succession, as

28 The beneficiaries to an estate would have an expectation to a benefit (but not a vested right) prior to the estate falling open. See De Waal MJ \& Schoeman-Malan, Law of Succession, 11-12. See also Rautenbach C, 'Introduction,' 12-16.

29 See De Waal MJ \& Schoemann-Malan MC, Law of Succession 5 ed (2015) 7-11 for a detailed discussion on this issue.

30 Rautenbach C, 'Administration of Estates' in The Law of Succession in South Africa, ed. Juanita J. \& Rautenbach C. (Cape Town: Oxford, 2009), 241.

31 See s 37C of the Pension Funds Act 24 of 1956 where it states that ' $\mathrm{n}$ ] otwithstanding anything to the contrary contained in any law or in the rules of a registered fund, any benefit payable by such a fund upon the death of a member, shall, subject to a pledge in accordance with section 19 (5) (b) (i) and subject to the provisions of section 37A (3) and 37D, not form part of the assets in the estate of such a member'. 
The Impact of the South African Law of Succession and Administration of Estates on South African Muslims

it is not regarded as an asset in the deceased estate. ${ }^{32}$ This would be the more preferred view within the South African context. I agree with this opinion.

Assets within the estate include movable assets, immovable assets, as well as claims in favour of the estate. The claims against these assets (in order of priority) are referred to hereafter as liability claims, testate succession claims, and intestate succession claims. ${ }^{33}$ The estate must first be liquidated by settling the liability claims. The remainder (if any) must then be distributed in terms of the law of testate and intestate succession.

There are three matrimonial property systems that govern marriages in terms of the Matrimonial Property Act 88 of 1984. These systems could be referred to as in community of property, ${ }^{34}$ out of community of property

32 See Mufti Muhammad Taqi Usmani 'Entitlement to Death Benefits Payable by Pension Funds' where he states that the grants given to the dependants of a deceased in terms of the Pension Funds Act 24 of 1956 are not subject to the rules of inheritance. Available at http://www.muftitaqiusmani.com/index. php?option $=$ com_content\&view $=$ article\&id $=54$ :entitlement-to-death-benefitspayable-by-pension-funds\&catid $=10$ :economics\&Itemid $=17$, accessed on 11 January 2015. See also s 37 C of the Pension Funds Act 24 of 1956 that specifically states that the death benefits in favour of the dependants of the deceased does not form part of a deceased's estate.

33 See De Waal MJ \& Schoemann-Malan MC, Law of Succession, 3.

34 One joint estate comes into existence upon conclusion of a marriage in community of property. The joint estate would consist of all the assets and liabilities that both spouses had prior to and after entering into the marriage. There are however a few exceptions to this rule. See Skelton A \& Carnelley M (eds), Family Law in South Africa (Cape Town: Oxford, 2014), 72-73. See s 1 of the Matrimonial Property Act that states that the term joint estate 'means the joint estate of a husband and a wife married in community of property.' There are a number of South African Muslim theologians ( 'ulama $\overline{\text { ) }}$ who are of the opinion that a marriage in community of property is not permissible in terms of Islamic law. See Omar MS, The Islamic Law of Succession and its Application in South Africa (Durban: Butterworths, 1988), 11; and Muslim Judicial Council (SA) Fatwa Committee 'MJC Position on Succession Law and Related Matters' (2017) document on file with the author of this paper. See also Jamiatul Ulama Kwazulu Natal, 'Resolving a Community of Property Estate?' available at https://jamiat.org.za/resolving-a-community-ofproperty-estate/, accessed on 21 October 2017. 
without accrual, ${ }^{35}$ and out of community of property with accrual. ${ }^{36}$ This paper focuses on the estates of deceased persons who were married out of community of property without accrual. ${ }^{37}$ Two separate estates are retained after entering into a marriage that is out of community of property without accrual. The individual estates of each spouse would consist of the assets and liabilities obtained before and after entering into the marriage. ${ }^{38}$ It is possible that an asset within the deceased estate is subject to a lifelong usufruct in favour of an individual. ${ }^{39}$ Ownership of the asset would pass to the beneficiaries thereof in terms of the law of succession. The right to use, enjoy, and take the fruits of the asset would be suspended until the usufruct comes to an end. An example of a

35 Two separate estates are retained after entering into a marriage that is out of community of property with the accrual system. The individual estates of each spouse would consist of the assets and liabilities obtained before and after conclusion of the marriage. See Skelton A \& Carnelley M (eds), Family Law in South Africa, 72-73.

36 S 2 of the Matrimonial Property Act 88 of 1984 that states that '[e]very marriage out of community of property in terms of an antenuptial contract by which community of property and community of profit and loss are excluded, which is entered into after the commencement of this Act, is subject to the accrual system specified in this chapter, except in so far as that system is expressly excluded by the antenuptial contract.' Section 4 of the Matrimonial Property Act 88 of 1984 states that '[ $t]$ he accrual of the estate of a spouse is the amount by which the net value of his estate at the dissolution of his marriage exceeds the net value of his estate at the commencement of that marriage.' The spouse who has shown a smaller accrual estate can share in the growth of the accrual estate of the other spouse upon death or divorce. See Skelton A \& Carnelley M (eds), Family Law in South Africa, 72-73.

37 Two separate estates are retained after entering into a marriage that is out of community of property without accrual. The individual estates of each spouse would consist of the assets and liabilities obtained before and after entering into the marriage. Skelton A \& Carnelley M (eds), Family Law in South Africa, 73.

38 Skelton A \& Carnelley M (eds), Family Law in South Africa, 73.

39 A usufruct can be defined 'as a personal servitude giving the usufructuary a limited real right to use another person's property and to take its fruits with the obligation to return the property eventually to the owner, retaining its essential quality' See De Waal MJ \& Schoemann-Malan MC, Law of Succession 5 ed (2015) 164. 
The Impact of the South African Law of Succession and Administration of Estates on South African Muslims

lifelong usufruct would be where a husband registers a lifelong usufruct of his family home in favour of his wife. ${ }^{40}$

\section{LIABILITY CLAIMS}

Liability claims are the first claims that must be deducted from the gross estate and they take priority over testate and intestate succession claims. ${ }^{41}$ Liability claims can be broadly divided into administration costs and debt. Administration costs include funeral costs, maintenance, estate duty, bank charges, transfer fees, executor's fees, and Master's fees. There is an order of priority between these claims in the event where the liability claims exceed the value of the gross estate. This discussion, however, is beyond the scope of this paper and is not discussed any further herein.

\section{Administration costs}

Administration costs include funeral costs, maintenance, estate duty, bank charges, transfer fees, executor's fees, and Master's fees. The funeral costs are restricted to those expenses reasonably needed in order to prepare the deceased for burial as well as the burial proceedings. The average Christian funeral cost in South Africa is approximately R12 000.00. ${ }^{42}$ This would include the cost of

40 See De Waal MJ \& Schoemann-Malan MC, Law of Succession 5 ed., 163-166 for a detailed discussion on this issue. The Muslim Judicial Council based in the Western Cape in South Africa encourages the registration of a usufruct in instances where it is deemed necessary. Muslim Judicial Council (SA) Fatwa Committee 'MJC Position on Succession Law and Related Matters' (2017) document on file with the author of this paper. The Muslim Judicial Council is one of the oldest Islamic religious institutions in South Africa.

$41 \quad$ See De Waal MJ \& Schoemann-Malan MC, Law of Succession 4 ed., 3.

42 Funeral Cover Quotes, 'Apart from Cultural Beliefs, Cost is a Big Factor in Deciding on Cremation,' available at http://funeral-cover-quotes.co.za/326/costs/ cremation-high-funeral-cost, accessed on 27 June 2016. 
a tombstone..$^{43}$ Maintenance claims include those claims by certain dependants that are in need of it. This would include claims by certain inheriting intestate beneficiaries (if any). It is possible that an intestate beneficiary could claim maintenance as well as inherit in terms of the law of testate and/or intestate succession.

There are certain requirements that must be met in order to successfully claim future maintenance from a deceased estate. ${ }^{44}$ South African Muslim women have gone to courts to claim future maintenance against the estates of their deceased husbands. They have also claimed intestate succession claims in terms of South African law provisions. ${ }^{45}$ Estate duty, bank charges, transfer fees, executor's fees, and Master's fees are all claims against the deceased estate and are required to be settled in order to successfully administer the estate within the South African context. ${ }^{46}$

\section{Debt}

Debt claims can be divided into secured debt and unsecured debt. A mortgage bond is an example of a secured debt whereas an unpaid dower is an example

43 See s 4(a) of Estate Duty Act 4 of 1955 where it states that 'The net value of any estate shall be determined by making the following deductions from the total value of all property included therein in accordance with section 3, that is to say - (a) so much of the funeral, tombstone and death-bed expenses of the deceased which the Commissioner considers to be fair and reasonable...' It is interesting to note that a claim for a tombstone would not be permitted in terms of Islamic law as it is not deemed as a necessary expense. The average cost of a Muslim funeral is approximately between R2 500.00 and R5 000.00. See Compare Guru, 'Funerals in South Africa and what they Cost - Muslim Burial Culture,' available at http:// compareguru.co.za/news/funeral-customs-in-sa-and-what-they-cost/, accessed on 3 January 2017. See also Hartley U, 'The Cost of Death' http://www.vocfm.co.za/ the-cost-of-death/, accessed on 18 June 2016.

44 Jamneck J., 'Freedom of Testation,' in The Law of Succession in South Africa, ed. Juanita J. \& Rautenbach C. (Cape Town: Oxford, 2009), 122-124.

45 See Daniels v Campbell NO \& Others 2004 (5) SA 331 (CC); and Hassam v Jacobs NO \& Others 2009 (5) SA 572 (CC).

46 See De Waal MJ \& Schoeman-Malan MC, Law of Succession (Cape Town: Juta, 2015), 244. It should be noted that these claims are not expressly stated in the classical texts governing the laws of succession and administration of estates in terms of Islamic law. They are, however, incidental costs that are required to be settled in order to successfully liquidate and distribute an estate in terms of South African law. 
The Impact of the South African Law of Succession and Administration of Estates on South African Muslims

of an unsecured debt. It should be noted that a debt prescribes (is cancelled) upon the elapse of a certain amount of time. ${ }^{47}$

\section{TESTATE SUCCESSION CLAIMS}

Testate succession claims must be settled from the remainder of the gross estate (if any) after the liability claims have been deducted. ${ }^{48}$ The remainder is referred to hereafter as the net estate. ${ }^{49}$ The net estate is further divided into the testate estate and intestate estate. The testate estate is governed by the law of testate succession and the intestate estate is governed by the law of intestate succession. South African law recognises the common law principle of freedom of testation. ${ }^{50}$ A testator or testatrix may appoint beneficiaries to inherit from his or her estate in terms of a valid will. There are few limitations that apply to this freedom. ${ }^{51}$ A person appointed to inherit in terms of a will is referred to hereafter as a testate beneficiary. This section looks at the appointments in terms of a will. There are also other ways in which the appointment can be done. An explanation of these ways is beyond the scope of this paper. ${ }^{52}$

47 See s 11 of the Prescription Act 68 of 1969 where it states that '[p]eriods of prescription of debts. The periods of prescription of debts shall be the following:(a) thirty years in respect of - (i) any debt secured by mortgage bond; (ii) any judgment debt; (iii) any debt in respect of any taxation imposed or levied by or under any law; (iv) any debt owed to the State in respect of any share of the profits, royalties or any similar consideration payable in respect of the right to mine minerals or other substances; (b) fifteen years in respect of any debt owed to the State and arising out of an advance or loan of money or a sale or lease of land by the State to the debtor, unless a longer period applies in respect of the debt in question in terms of paragraph (a) ; (c) six years in respect of a debt arising from a bill of exchange or other negotiable instrument or from a notarial contract, unless a longer period applies in respect of the debt in question in terms of paragraph (a) or (b); (d) save where an Act of Parliament provides otherwise, three years in respect of any other debt.' It should be noted that debts do not prescribe in terms of Islamic law. A debtor would always be liable in terms of Islamic law to pay his or her creditor.

48 A Muslim person is only permitted to bequeath up to $1 / 3$ of the net estate. A person dies partly intestate when he or she bequeaths less than $1 / 3$ of the net estate in a will. The remaining $2 / 3$ must be distributed in terms of the laws of intestate succession. The complete $3 / 3$ of the net estate is distributed in terms of the laws of intestate succession when there is no will.

49 See De Waal MJ \& Schoemann-Malan MC, Law of Succession 5 ed., 245.

50 Jamneck J., 'Freedom of Testation,' 115.

51 Jamneck J., 'Freedom of Testation,' 115.

52 For further discussion on this issue, see De Waal MJ \& Schoemann-Malan MC, Law of Succession 4 ed., 3 
The person appointing a testate beneficiary is referred to as a testator (male) or testatrix (female). A testate beneficiary would inherit only if he or she is neither prevented from inheriting due to a disqualification nor prevented from inheriting due to a total exclusion. These persons are referred to hereafter as 'inheriting' testate beneficiaries. ${ }^{53}$ The laws of testate disqualifications and testate exclusions are discussed in the forthcoming sections of this paper.

\section{The Law of Wills}

A Muslim testator or testatrix may technically bequeath his or her estate in terms of the Islamic law of succession in terms of the principle of freedom of testation. ${ }^{54}$ This could be referred to as an Islamic will. A Muslim testator or testatrix may also technically bequeath his or her estate to a trust and stipulate that the trustees must administer the trust in terms of the Islamic law of succession. ${ }^{55}$ A further discussion on this method is beyond the scope of this paper.

There are certain conditions that must be met in order for a will (including an Islamic will) to be valid in terms of South African law. ${ }^{56}$ A will must be

53 See Paleker M., 'Capacity to Inherit,' in The Law of Succession in South Africa, ed. Juanita J. \& Rautenbach C. (Cape Town: Oxford, 2009), 99-114.

54 See also Rautenbach C, Gokul R, Bernhard BN, and Goolam MM 'Law of Succession' in Rautenbach C \& Goolam NMI Introduction to Legal Pluralism in South Africa. Part II Religious Legal Systems (2002) 107-108.

55 Rautenbach C, Gokul R, Bernhard BN \& Goolam MMI 'Law of Succession' in Rautenbach C \& Goolam NMI Introduction to Legal Pluralism in South Africa. Part II Religious Legal Systems (2002) 108.

56 See s 2(1)(a) of the Wills Act 7 of 1953 states that 'no will executed on or after the first day of January, 1954, shall be valid unless - (i) the will is signed at the end thereof by the testator or by some other person in his presence and by his direction; and (ii) such signature is made by the testator or by such other person or is acknowledged by the testator and, if made by such other person, also by such other person, in the presence of two or more competent witnesses present at the same time; and (iii) such witnesses attest and sign the will in the presence of the testator and of each other and, if the will is signed by such other person, in the presence also of such other person; and (iv) if the will consists of more than one page, each page other than the page on which it ends, is also so signed by the testator or by such other person anywhere on the page; and (v) if the will is signed by the testator by the making of a mark or by some other person in the presence and by the direction of the testator, a commissioner of oaths certifies that he has satisfied himself as to the identity of the testator and that the will so signed is the will of the testator, and each page of the will, excluding the page on which his 
The Impact of the South African Law of Succession and Administration of Estates on South African Muslims

executed in writing. ${ }^{57}$ It must be signed by the testator or testatrix aged 16 years or older and must be signed in the presence of at least two competent witnesses. ${ }^{58}$ The witnesses must be 14 years or older and must sign the will in the presence of the testator or testatrix and each other. ${ }^{59}$ It is interesting to note that a minor acquires full capacity to act subsequent to marriage. ${ }^{60}$ This could be as young as 12 years of age for a female and 14 years of age for a male. ${ }^{61} \mathrm{~A}$ female as young as 12 years of age and a male as young as 14 years of age may therefore technically execute a will and witness a will in terms of this rule. The unequal treatment regarding the age requirements of males and females raises the question of discrimination based on sex.

\section{Testate Succession Disqualifications and Substitution}

A testate succession disqualification prevents a testate beneficiary from inheriting due to the presence of certain attributes. The two types of testate succession disqualifications that are looked at in this paper are divorce and

certificate appears, is also signed, anywhere on the page, by the commissioner of oaths who so certifies: Provided that - (aa) the will is signed in the presence of the commissioner of oaths in terms of subparagraphs (i), (iii) and (iv) and the certificate concerned is made as soon as possible after the will has been so signed; and ( $\mathrm{bb}$ ) if the testator dies after the will has been signed in terms of subparagraphs (i), (iii) and (iv) but before the commissioner of oaths has made the certificate concerned, the commissioner of oaths shall as soon as possible thereafter make or complete his certificate, and sign each page of the will, excluding the page on which his certificate appears...'

57 Section 2(1) of the Wills Act 7 of 1953 where states that a will is 'a codicil and any other testamentary writing...'

58 Section 2(1) of the Wills Act 7 of 1953. See also s 4 of the Wills Act 7 of 1953 where it states that '[e]very person of the age of sixteen years or more may make a will unless at the time of making the will he is mentally incapable of appreciating the nature and effect of his act, and the burden of proof that he was mentally incapable at that time shall rest on the person alleging the same.'

59 Wood-Bodley M, 'Formalities for a Will,' in The Law of Succession in South Africa, ed. Juanita J. \& Rautenbach C. (Cape Town: Oxford, 2009), 66. See also s 1 of the Wills Act 7 of 1953 where it states that a competent witness 'means a person of the age of fourteen years or over who at the time he witnesses a will is not incompetent to give evidence in a court of law...'

60 This is in terms of the common law. See Skelton A \& Carnelley M (eds), Family Law in South Africa, 58.

61 Kruger H \& Skelton A (eds), The Law of Persons in South Africa (Cape Town: Oxford, 2012), 129. See also s 12(2)(a) of the Children's Act 38 of 2005. 
unworthiness. ${ }^{62}$ A testate beneficiary who is a previous spouse of the testator or testatrix would be disqualified from inheriting as such if their marriage was dissolved less than three months prior to the testator or testatrix having died. The disqualification would cease to exist upon completion of three months. The exception to the rule would be where it appears from the will that the testator or testatrix intended to benefit his or her previous spouse notwithstanding the divorce. The disqualification is in terms of $\mathrm{s} 2 \mathrm{~B}$ of the Wills Act. ${ }^{63}$ The wording of $\mathrm{s} 2 \mathrm{~B}$ refers to spouses who are subject to divorce or annulment. It is not clear as to whether an Islamic revocable divorce or Islamic irrevocable divorce is applicable to this section. The section was added to the Wills Act in 1992. ${ }^{64}$ It is more likely that the intended purpose of the section was for persons who were married in terms of the Marriage Act 25 of $1961 .{ }^{65}$ A testate beneficiary would be disqualified from inheriting as such in the event where he or she is deemed to be an unworthy person. Examples of unworthiness would be where a testator or testatrix killed the testator or testatrix unlawfully, where he or she destroyed the will of the testator or testatrix, where he or she forged the will of the testator or testatrix, where he or she caused the testator or testatrix to lead an immoral life, and where he or she had been enriched through a crime. ${ }^{66}$

A testate benefit that was bequeathed to a disqualified testate beneficiary would vest in a substitute if substitution was provided for in terms of the will, if common law accrual applies, or where substitution applies by operation of law. The benefit would devolve in terms of the law of intestate succession if none of the three instances of substitution applies.

62 For a discussion on this issue, see Paleker M., 'Capacity to Inherit,' 105-112.

See s 2B of Wills Act 7 of 1953 which states that '[i]f any person dies within three months after his marriage was dissolved by a divorce or annulment by a competent court and that person executed a will before the date of such dissolution, that will shall be implemented in the same manner as it would have been implemented if his previous spouse had died before the date of the dissolution concerned, unless it appears from the will that the testator intended to benefit his previous spouse notwithstanding the dissolution of his marriage.' It should be noted that a revocable divorce as applied in terms of Islamic law has the opposite effect. A spouse who is subject to a revocable divorce would inherit as long as the waiting period has not elapsed. This period is approximately three lunar months. The divorce becomes final upon conclusion of the waiting period.

64 Law of Succession Amendment Act 43 of 1992.

65 See Marriage Act 25 of 1961.

66 See Paleker M., 'Capacity to Inherit,' 105-112. 
The Impact of the South African Law of Succession and Administration of Estates on South African Muslims

The first instance would be where substitution was provided for in terms of the will. This could also be referred to as testamentary substitution. ${ }^{67}$ An example of testamentary substitution would be where $X$ bequeaths $1 / 3$ of her net estate in favour of $Y$ (instituted beneficiary). She further states that the $1 / 3$ must be given to $Z$ (substituted beneficiary) in the event where $Y$ is disqualified from inheriting the benefit. $\mathrm{Z}$ would inherit the benefit if $\mathrm{Y}$ is disqualified.

The second instance would be where substitution is provided for in terms of statute. This could be referred to as statutory substitution. Statutory substitution would apply in the event where testamentary substitution does not find application. ${ }^{68}$ An example of statutory substitution would be where $\mathrm{X}$ bequeaths $1 / 3$ of his net estate in favour of his Christian son (Y) who subsequently kills him. The descendants of Y (if any) would substitute $Y$ as he would be disqualified because he killed the testator. ${ }^{69}$

The third instance in this regard would be where substitution is provided for in terms of the common law. This is also referred to as common law accrual. Common law accrual can only operate in the event where no provision was made for substitution by the testator or testatrix and statutory substitution does not apply. Common law accrual is the right of a co-legatee or a co-heir to inherit the benefit that his or her co-legatee or co-heir cannot or does not wish to inherit. ${ }^{70}$ An example of common law accrual would be where $\mathrm{X}$ leaves behind a full sister and a full brother as the only relatives. $X$ bequeaths $1 / 3$ of the net estate in favour of her full brother and her full sister. The full sister

67 De Waal MJ \& Schoeman-Malan, Law of Succession, 143-144.

68 See Van Der Linder A, 'Content of Wills - Substitution, Usufruct, and Accrual,' in The Law of Succession in South Africa, ed. Juanita J. \& Rautenbach C. (Cape Town: Oxford, 2009), 153.

69 See s $2 \mathrm{C}(2)$ of the Wills Act 7 of 1953 which states that '[i]f a descendant of the testator, whether as a member of a class or otherwise, would have been entitled to a benefit in terms of the provisions of a will if he had been alive at the time of death of the testator, or had not been disqualified from inheriting, or had not after the testator's death renounced his right to receive such a benefit, the descendants of that descendant shall, subject to the provisions of subsection (1), per stirpes be entitled to the benefit, unless the context of the will otherwise indicates.' See also Van Der Linder A, 'Content of Wills - Substitution, Usufruct, and Accrual,' 153166. It should be noted that statutory substitution does not apply in terms of the Islamic law of testate and intestate succession. The benefit due to a disqualified testate or intestate beneficiary would be redirected into the intestate estate and distributed in terms of the Islamic law of intestate succession.

70 See Van Der Linder A, 'Content of Wills - Substitution, Usufruct, and Accrual,' 164-165. 
predeceases $X$. The full brother would inherit the complete $1 / 3$ in terms of common law accrual. ${ }^{71}$

A testate benefit that would have been due to a disqualified testate beneficiary would devolve in terms of the law of intestate succession if none of the three instances of substitution finds application. ${ }^{72}$ An example of this would be where $\mathrm{X}$ bequeaths $1 / 3$ of her net estate in favour of her full brother. She leaves behind a son, a full brother, and a daughter of the full brother as the only relatives. Her full brother, however, unlawfully kills her. The 1/3 would devolve in terms of the law of intestate succession. The son would inherit the complete $3 / 3$ in terms of the law of intestate succession. ${ }^{73}$ The daughter of the full brother would not substitute him.

\section{Testate Succession Exclusions}

A testate succession exclusion would prevent a testate beneficiary from inheriting due to the presence of one or more other persons. The exclusion could be partial or in full. There are no direct exclusions in terms of South African law. There are, however, indirect exclusions. An example of a testate succession exclusion would be where $\mathrm{X}$ dies leaving behind a net estate of R100 000.00 and a daughter and a full brother as his only relatives. He bequeaths the R100 000.00 in favour of his full brother. His minor daughter is not able to support herself and is in need of R20 000.00 maintenance and R10 000.00 for her education. The minor daughter would then partially exclude the full brother from inheriting the entire R100 000.00 and would only inherit R70 000.00. This could also be seen as an indirect limitation to the right to freedom of testation. ${ }^{74}$

71 See Van Der Linder A 'Content of Wills - Substitution, Usufruct, and Accrual' in Juanita J \& Rautenbach C, The Law of Succession in South Africa (2009) 164-165.

72 See De Waal MJ \& Schoemann-Malan MC, Law s of Succession 4 ed (2008) 3.

73 See s 1(1) of the Intestate Succession Act 81 of 1987 that states that "[i]f after the commencement of this Act a person (hereinafter referred to as the "deceased") dies intestate, either wholly or in part, and - ... (b) is survived by a descendant, but not by a spouse, such descendant shall inherit the intestate estate.'

74 See Jamneck J., 'Freedom of Testation,' 122. It is stated that 'maintenance and education of minor children remains an obligation on the estate and does not die with the testator.' It should be noted that Islamic law does not generally include a right to claim future maintenance from a deceased estate. Islamic law does however include a right to compulsory inheritance as an intestate beneficiary. The daughter in this example would have inherited $1 / 2$ of the intestate estate in terms of Islamic law. She would inherit this share irrespective of being either destitute or affluent. 
The Impact of the South African Law of Succession and Administration of Estates on South African Muslims

A surviving spouse would have a claim for future maintenance in terms of the Maintenance of Surviving Spouses Act 27 of 1990. S 2(1) of the Act states that '[i]f a marriage is dissolved by death after the commencement of this Act the survivor shall have a claim against the estate of the deceased spouse for the provision of his reasonable maintenance needs until his death or remarriage insofar as he is not able to provide therefore from his own means and earnings. ${ }^{75}$ The section applies to Islamic law monogamous marriages as well as Islamic law polygynous marriages. ${ }^{76}$

\section{Testate Succession Limitations}

Testators have quite wide freedom of testation in terms of South African law. ${ }^{77}$ The principle of freedom of testation is, however, limited to a certain extent. The courts will not enforce a condition in a will that is found to be contra bona mores (against public policy). An example of a condition that is against public policy would be where $X$ bequeaths $1 / 3$ of his net estate in favour of his unmarried full brother on condition that he never marries. The condition would be deemed contra bona mores and it would be regarded as if it had never been written. ${ }^{78}$ Discriminatory conditions found in a will can be declared invalid on constitutional grounds. ${ }^{79}$ Section 9(3) read with s 9(4) of the Constitution of

See Khan MM, The Noble Qur'an - English Translation of the Meanings and Commentary $1404 \mathrm{H}$ (4) 11 where it states that 'Allah commands you as regards your children's (inheritance); to the male, a portion equal to that of two females; if (there are) only daughters, two or more, their share is two thirds of the inheritance; if only one, her share is half...'

75 See s 2(1) of the Maintenance of Surviving Spouses Act 27 of 1990 where it states that '[i]f a marriage is dissolved by death after the commencement of this Act the survivor shall have a claim against the estate of the deceased spouse or the provision of his reasonable maintenance needs until his death or remarriage in so far as he is not able to provide therefore from his own means and earnings.'

76 See Daniels v Campbell NO \& Others 2004 (5) SA 331 (CC); and Hassam v Jacobs NO \& Others 2008 (4) All SA 350 (C).

77 Jamneck J., 'Freedom of Testation,' 126.

78 Jamneck J., 'Freedom of Testation,' 117-118. Islamic law has a similar provision and the condition would also be deemed as if it had never been written. See alZuhaylī, W., al-Fiqh al-Islāmī wa Adillatuh, vol. 8 (Damascus: Dār al-Fikr, 1989), 24-25. It is interesting to note that the same example is found within both legal systems.

79 Jamneck J., 'Freedom of Testation,' 122-126. See also See De Waal MJ \& Schoemann-Malan MC, Law s of Succession 4 ed (2008) 139. 
South Africa has the effect of prohibiting unfair discrimination on a number of grounds which include sex, gender, religion, and birth. ${ }^{80}$

Testamentary power must be exercised by a testator or testatrix himself or herself. He or she may generally not delegate others to choose who his or her beneficiaries under his or her will should be. ${ }^{81}$ The delegation of testamentary power would be invalid in a situation where the grantee thereof is given unlimited discretion. This could be referred to as a general power of appointment. An example of general power of appointment would be where $\mathrm{X}$ states in his will that the beneficiaries of his estate shall be decided by his daughter $\mathrm{Y}^{82}$ There are few exceptions where a testator or testatrix may delegate his or her testamentary power. ${ }^{83}$ An example of an exception would be where a testator creates a charitable trust in his will and leaves it up to the executor to appoint beneficiaries in terms of the trust. ${ }^{84}$

\section{Testate Succession Adiation, Repudiation, Substitution and Collation}

Adiation within the context of testate succession is when a testate beneficiary accepts a benefit. A testate beneficiary would acquire an enforceable right to a benefit upon adiation. ${ }^{85}$ Adiation must, however, take place subsequent to "dies cedit". ${ }^{86}$ There is a presumption in favour of adiation. The presumption would be rebutted through repudiation. ${ }^{87} \mathrm{~A}$ repudiated testate benefit would vest in a substitute in certain instances. An example of this would be where X bequeaths $1 / 8$ of his intestate estate in favour of his wife and 7/8 in favour of his son. The son renounces the testate benefit after $\mathrm{X}$ died. The $7 / 8$ would be

80 See s 9 of the Constitution of Republic of South Africa, 1996 where it states that '... (3) The state may not unfairly discriminate directly or indirectly against anyone on one or more grounds, including race, gender, sex, pregnancy, marital status, ethnic or social origin, colour, sexual orientation, age, disability, religion, conscience, belief, culture, language and birth 4) No person may unfairly discriminate directly or indirectly against anyone on one or more grounds in terms of subsection. (3). National legislation must be enacted to prevent or prohibit unfair discrimination (5) Discrimination on one or more of the grounds listed in subsection (3) is unfair unless it is established that the discrimination is fair.'

81 Jamneck J., 'Freedom of Testation,' 126.

82 See De Waal MJ \& Schoeman-Malan, Law of Succession, 49.

83 See De Waal MJ \& Schoeman-Malan, Laws of Succession, 47-51.

84 Jamneck J., 'Freedom of Testation,' 127.

85 It should be noted that this is also the position in terms of Islamic law.

86 Rautenbach C, 'Introduction,' 12-16.

87 See De Waal MJ \& Schoeman-Malan MC, Law of Succession 4 ed (2008) 193. 
The Impact of the South African Law of Succession and Administration of Estates on South African Muslims

inherited by the widow as a statutory substitute in terms of s $2 \mathrm{C}(1)$ of the Wills Act 7 of $1953 .{ }^{88}$

The principle of collation is applicable to the law of testate succession. The executor or executrix of a deceased estate must, under certain circumstances, take into account the benefits bestowed upon certain heirs by the deceased during his or her lifetime when distributing the assets in the deceased's estate. ${ }^{89}$ The principle of collation is based on the assumption that the parent or grandparent intended that his or her assets must be equally divided amongst his or her children and further descendants. ${ }^{90}$ The principle of collation applies to heirs and not legatees. ${ }^{91}$

An example of how the principle of collation applies would be where $\mathrm{X}$ dies leaving behind a testate estate of R50 000.00. ${ }^{92}$ He bequeaths the entire net estate in favour of his son and daughter. X, however, gave his son R10 000.00 in order to start a business. The money was given two weeks prior to him dying. The son and daughter would then inherit R25 000.00 each if collation is not called for by the daughter. If the daughter does, however, call for collation to take place, then the R10 000.00 given to the son would be taken into account and added to the R50 000.00. The daughter would inherit R30

88 See s 2C(1) of the Wills Act 7 of 1953 which states that '[i]f any descendant of a testator excluding a minor or a mentally ill descendant, who, together with the surviving spouse of the testator, is entitled to a benefit in terms of a will renounces his right to receive such a benefit, such benefit shall vest in the surviving spouse.' See also Moosa NO \& Others v Harnaker and Others 2017 (6) SA 425 (WCC) where this matter was discussed. It should be noted that the widow would not automatically inherit the renounced benefit in terms of Islamic law. There is nothing in terms of Islamic law that prevents the son from gifting the 7/8 in favour of the widow. The outcome would then effectively be the same in terms of the two legal systems.

89 See De Waal MJ \& Schoeman-Malan, Law of Succession, 204.

90 See De Waal MJ \& Schoeman-Malan, Law of Succession, 204.

91 An heir 'is a beneficiary who inherits a testator's entire estate, a portion thereof, or the residue thereof. An heir is distinguished from a legatee, who is a beneficiary who inherits a specific asset.' See Rautenbach C, 'Introduction,' 9.

92 See De Waal MJ \& Schoeman-Malan MC, Law of Succession 5 ed., 204-209 for a discussion on the doctrine of collation. 
000.00 and the son would inherit R20 000.00 as he had already received R10 000.00 two weeks prior to the death of the testator. ${ }^{93}$

\section{INTESTATE SUCCESSION CLAIMS}

Intestate succession claims are settled from the remainder of the net estate after all testate succession claims have been deducted. The remainder is referred to hereafter as the intestate estate. Persons who are eligible to inherit from the intestate estate are referred to hereafter as intestate beneficiaries. An intestate beneficiary (in terms of this paper) is a person who has one or more intestate succession ties to the deceased person. An intestate beneficiary would inherit only in the event that he or she is neither disqualified from inheriting due to the presence of an intestate disqualification nor totally excluded from inheriting due to the presence of an intestate exclusion. ${ }^{94}$ Intestate beneficiaries who are neither disqualified nor totally excluded are referred to hereafter as 'inheriting' intestate beneficiaries. Inheriting intestate beneficiaries comprise both males and females and can be disinherited through testacy. ${ }^{95}$ The shares of intestate beneficiaries are prescribed by law. The rules referred to in this paper apply to the estates of both male and female deceased persons.

\section{Intestate Succession Ties}

The ties that are discussed in this section are affinity, consanguinity, adoption, surrogacy, acceptance, and union. ${ }^{96} \mathrm{~A}$ widow or widower is related

93 See De Waal MJ \& Schoeman-Malan MC, Law of Succession 5 ed., 204-209 for a discussion on the doctrine of collation. It should be noted that the principle of collation does not apply in terms of the Islamic law of succession. A testate beneficiary would always inherit the complete testate succession benefit even if he or she received a gift from the testator or testatrix prior to his or her death.

94 See De Waal MJ \& Schoeman-Malan MC in Law of Succession (2015) 115-124.

95 Jamneck J., 'Freedom of Testation,' 122. It states that a 'testator has complete freedom to disinherit his or her children.' This is different to Islamic law where disinheritance of inheriting intestate beneficiaries is not permitted unless the inheriting intestate beneficiaries consent thereto subsequent to the testator or testatrix having died.

96 A child born as a result of surrogacy can inherit from his commissioned parents. See s 297(2) of the Children's Act 38 of 2005. A lawfully adopted child would have the capacity to inherit from his adoptive parents and vice versa. Their adoptive parents would be deemed his natural parents for all legal purposes. See Paleker M, 'Intestate Succession,' 22-23. See s 1(4)(e) and s 1(5) of the Intestate Succession Act 81 of 1987. 
The Impact of the South African Law of Succession and Administration of Estates on South African Muslims

to the deceased through affinity. A same sex domestic partner is deemed to be a spouse in terms of the Intestate Succession Act 81 of 1987 whereas a heterosexual domestic partner is not deemed to be a spouse for purposes of the legislation. This raises the question of discrimination. ${ }^{97} \mathrm{~A}$ further discussion on this issue is beyond the scope of this paper. ${ }^{98}$ Some of the consequences of monogamous and polygynous Islamic law marriages have been recognised for purposes of the South African law of succession. A surviving spouse to a de facto monogamous Islamic law marriage was recognised as a spouse for purposes of the Intestate Succession Act 81 of 1987 in Daniels v Campbell NO \& Others 2004 (5) SA 331 (CC). Surviving spouses to de facto polygynous marriages were recognised as surviving spouses for intestate purposes of the Intestate Succession Act 81 of 1987 in Hassam v Jacobs NO \& Others 2009 (5) SA 572 (CC). ${ }^{99}$ It must be noted that the South African law provisions are not in conformity with Islamic law. Islamic law was therefore not applied to the distribution of the estates in this regard.

A biological son is related to the deceased through consanguinity. This includes a child born from a marriage that was contracted in terms of Islamic law. Children born from Islamic law marriages do inherit for purposes of the Intestate Succession Act 81 of 1987. The children born from these marriages do not inherit as children born in wedlock but rather as children born out of wedlock. ${ }^{100}$ This situation raises the question of discrimination based on

97 See Volks $v$ Robinson 2005 (5) BCLR 446 (CC) where it was held that heterosexual domestic partners are not eligible to inherit in terms of the Intestate Succession Act 81 of 1987 in their capacities as surviving Spouses. It is quite interesting to note that in Gory v Kolver 2007 (4) SA 97 (CC) the court held that the Intestate Succession Act applies to same sex domestic partners. This was later confirmed in Duplan v Loubser 2015 ZAGPPHC 849. It should be noted that Duplan v Loubser was heard after the enactment of the Civil Union Act 17 of 2006.

98 It should be noted that Islamic law does not include adoption and surrogacy as intestate succession ties.

99 See Intestate Succession Act 81 of 1987. See also Daniels $v$ Campbell NO \& Others 2004 (5) SA 331 (CC); and Hassam v Jacobs NO \& Others 2009 (5) SA 572 (CC).

100 See s 1(2) of the Intestate Succession Act 81 of 1987 where it states that '[n] otwithstanding the provisions of any law or the common or customary law, but subject to the provisions of this Act and sections 40(3) and 297(1)(f) of the Children's Act, 2005 (Act No. 38 of 2005), having been born out of wedlock shall not affect the capacity of one blood relation to inherit the intestate estate of another blood relation.' 
marital status and birth and can be challenged on constitutional grounds. ${ }^{101} \mathrm{~A}$ further discussion on this is beyond the scope of this paper. An adopted child is deemed to be the child of his or her adoptive parents and vice versa for purposes of the Intestate Succession Act 81 of $1987 .{ }^{102}$ A surrogate child is deemed to be the child of the commissioning parents in terms of s 297 of the Children's Act

$\overline{101}$ See s 9(3) of the Constitution of the Republic of South Africa, 1996 where it states that ' $[\mathrm{t}]$ he state may not unfairly discriminate directly or indirectly against anyone on one or more grounds, including race, gender, sex, pregnancy, marital status, ethnic or social origin, colour, sexual orientation, age, disability, religion, conscience, belief, culture, language and birth. (4) No person may unfairly discriminate directly or indirectly against anyone on one or more grounds in terms of subsection (3). National legislation must be enacted to prevent or prohibit unfair discrimination. (5) Discrimination on one or more of the grounds listed in subsection (3) is unfair unless it is established that the discrimination is fair.'

102 See s 1(4)of the Intestate Succession Act 81 of 1987 where it states that '...(e) an adopted child shall be deemed - (i)to be a descendant of his adoptive parent or parents; (ii) not to be a descendant of his natural parent or parents, except in the case of a natural parent who is also the adoptive parent of that child or was, at the time of the adoption, married to the adoptive parent of the child'; and s 1(5) of the Intestate Succession Act 81 of 1987 where it states that '[i]f an adopted child in terms of subsection (4)(e) is deemed to be a descendant of his adoptive parent, or is deemed not to be a descendant of his natural parent, the adoptive parent concerned shall be deemed to be an ancestor of the child, or shall be deemed not to be an ancestor of the child, as the case may be.'; and s 20(2) of the Child Care Act 74 of 1983 where it states that '[a]n adopted child shall for all purposes whatever be deemed in law to be the legitimate child of the adoptive parent, as if he was born of that parent during the existence of a lawful marriage.' See also Paleker M, 'Intestate Succession,' 22. The consequences that flow from a South African law adoption are prohibited in terms of Islamic law. Adoptive parents may not legally replace biological parents in terms of Islamic law. See Khan MM, The Noble Qur'an - English Translation of the Meanings and Commentary 1404H (33) 4 where it states that '.. . [a]nd he has not made your adopted sons your [true] sons'. A person may however assist a child by being his or her caregiver. This is also recommended in terms of Islamic law. See Al-Munajjid MS, 'Adoption is of Two Types - Forbidden and Prescribed,' available at https://islamqa.info/ en/10010, accessed on 28 October 2017. 
The Impact of the South African Law of Succession and Administration of Estates on South African Muslims

38 of $2005 .{ }^{103}$ The tie would be based upon the surrogacy agreement. ${ }^{104} \mathrm{~A}$ child conceived through artificial fertilisation is deemed to be the child of his or her birth mother in terms of s 40 of the Children's Act 38 of 2005 . He or she would be able to inherit as an intestate beneficiary of his or her biological father and vice versa, only if the biological father was married to the biological mother prior

103 A surrogate agreement is 'an agreement between a surrogate mother and a commissioning parent in which it is agreed that the surrogate mother will be artificially fertilised for the purpose of bearing a child for the commissioning parent and in which the surrogate mother undertakes to hand over such a child to the commissioning parent upon its birth, or within a reasonable time thereafter, with the intention that the child concerned becomes the legitimate child of the commissioning parent.' A commissioning parent is 'a person who enters into a surrogate motherhood agreement with a surrogate mother'See s 1 of the Children's Act 38 of 2005 .

104 See $\mathrm{s} 297$ of the Children's Act 38 of 2005 where it states that '(1) The effect of a valid surrogate motherhood agreement is that- (a) any child born of a surrogate mother in accordance with the agreement is for all purposes the child of the commissioning parent or parents from the moment of the birth of the child concerned; (b) the surrogate mother is obliged to hand the child over to the commissioning parent or parents as soon as is reasonably possible after the birth; (c) the surrogate mother or her husband, partner or relatives have no rights of parenthood or care of the child; (d) the surrogate mother or her husband, partner or relatives have no right of contact with the child unless provided for in the agreement between the parties; (e) subject to sections 292 and 293, the surrogate motherhood agreement may not be terminated after the artificial fertilisation of the surrogate mother has taken place; and (f) the child will have no claim for maintenance or of succession against the surrogate mother, her husband or partner or any of their relatives. (2) Any surrogate motherhood agreement that does not comply with the provisions of this Act is invalid and any child born as a result of any action taken in execution of such an arrangement is for all purposes deemed to be the child of the woman who gave birth to that child.' See also Paleker M, 'Intestate Succession,' 22. It should be noted that surrogacy as applied in South African law is not permitted in terms of Islamic law. See Al-Munajjid MS, 'Is it Permissible to Put the Sperm of the Husband and the Egg from the Wife in the Womb of the Second Wife?' https:// islamqa.info/en/83799, accessed on 28 October 2017. 
to the artificial fertilisation procedure. ${ }^{105}$ The question as to whether an Islamic law marriage would satisfy the requirement of marriage is an important one. An example of this would be where a Muslim couple is married for a number of years in terms of Islamic law only. They later have difficulty in conceiving a child and decide to attempt the artificial fertilisation procedure. It is not clear as to whether the Islamic law marriage would satisfy the requirement in terms of s 40 of the Children's Act. ${ }^{106}$ The different treatment between the biological parents raises the question of discrimination based on sex and marital status. ${ }^{107}$ A further discussion is beyond the scope of this paper.

105 See s 40 of the Children's Act 38 of 2005 that states that '(1) (a) Whenever the gamete or gametes of any person other than a married person or his or her spouse have been used with the consent of both such spouses for the artificial fertilisation of one spouse, any child born of that spouse as a result of such artificial fertilisation must for all purposes be regarded to be the child of those spouses as if the gamete or gametes of those spouses had been used for such artificial fertilisation. (b) For the purpose of paragraph (a) it must be presumed, until the contrary is proved, that both spouses have granted the relevant consent. (2) Subject to section 296, whenever the gamete or gametes of any person have been used for the artificial fertilisation of a woman, any child born of that woman as a result of such artificial fertilisation must for all purposes be regarded to be the child of that woman. (3) Subject to section 296, no right, responsibility, duty or obligation arises between a child born of a woman as a result of artificial fertilisation and any person whose gamete has or gametes have been used for such artificial fertilisation or the blood relations of that person, except when- (a) that person is the woman who gave birth to that child; or (b) that person was the husband of such woman at the time of such artificial fertilisation.' See also s 1(2) of the Intestate Succession Act 81 of 1987; Paleker M, 'Intestate Succession,' 22; and De Waal MJ \& Schoemann-Malan MC, Law of Succession 4 ed (2008) 115-116.

106 See s 40 of the Children's Act 38 of 2005. See s 1(2) of the Intestate Succession Act 81 of 1987. See also Paleker M, 'Intestate Succession,' 22. See De Waal MJ \& Schoemann-Malan MC, Law of Succession 4 ed (2008) 115-116.

107 It raises the question of discrimination based on sex as only the biological father would possibly be disqualified and not the biological mother. See s 9(3) of the Constitution of the Republic of South Africa, 1996 where it states that ' $[t]$ he state may not unfairly discriminate directly or indirectly against anyone on one or more grounds, including race, gender, sex, pregnancy, marital status, ethnic or social origin, colour, sexual orientation, age, disability, religion, conscience, belief, culture, language and birth. (4) No person may unfairly discriminate directly or indirectly against anyone on one or more grounds in terms of subsection (3). National legislation must be enacted to prevent or prohibit unfair discrimination. (5) Discrimination on one or more of the grounds listed in subsection (3) is unfair unless it is established that the discrimination is fair.' 
The Impact of the South African Law of Succession and Administration of Estates on South African Muslims

Customary law recognises a tie based on acceptance. ${ }^{108}$ This could be referred to as an acceptance tie. An example of where an acceptance tie applies to a person would be where X (who practices African culture) accepts a person (non-biological child) as his own child in accordance with customary law. The child would be deemed his descendant for intestate succession purposes. ${ }^{109}$ This tie is not recognised in terms of common law. The different treatment raises the question of discrimination. It should be noted that Islamic law does not recognise an acceptance tie. It is not clear as to what the situation of a non-biological child would be in the event where he was accepted as a child in accordance with customary law by a deceased person who was Muslim and who practiced African culture. Would Islamic law take preference or customary law? An example of such a person would be Nkosi Zwelivelile Mandela. He is also known as Mandla Mandela and is the chief of the Mvezo Traditional Council. He is the grandson of the former president Nelson Mandela. ${ }^{110} \mathrm{He}$ has reverted to Islam and has married a Muslim wife. ${ }^{111} \mathrm{~A}$ further discussion on this is beyond the focus of this paper.

Customary law recognises a tie based on union. This could be referred to as a union tie. An example of a union tie would be where $\mathrm{X}$ enters into a union with a woman in accordance with customary law for the purpose of providing him with children. The woman would be regarded as the descendant of X for purposes of the Intestate Succession Act 81 of $1987 .{ }^{112}$ The same question raised concerning the acceptance tie could also be raised here regarding the

108 See s 1 of the Reform of Customary Law of Succession and Regulation of Related Matters Act 11 of 2009 that states that a descendant 'means a person who is a descendant in terms of the Intestate Succession Act, and includes - (a) a person who is not a descendant in terms of the Intestate Succession Act, but who, during the lifetime of the deceased person, was accepted by the deceased person in accordance with customary law as his or her own child.'

109 See s 1 (a) of the Reform of Customary Law of Succession and Regulation of Related Matters Act 11 of 2009.

110 See Traditional Council 'Mvezo Komkhlu' available at http://www. mvezotraditionalcouncil.org.za/the-chief, accessed 20 October 2017.

111 See BBC News, 'Mandla Mandela's Conversion to Islam Sparks South Africa: Disquiet,' http://www.bbc.com/news/world-africa-35539541, accessed on 20 October 2017.

112 See s 1 (b) read with 2 (b) of the Reform of Customary Law of Succession and Regulation of Related Matters Act 11 of 2009 that states that 'a woman, other than the spouse of the deceased, with whom he had entered into a union in accordance with customary law for the purpose of providing children for his spouse's house must, if she survives him, be regarded as a descendant of the deceased' 
union tie. It is highly unlikely that the cultural practice would be applied by a Muslim as it is contrary to Islamic law provisions regarding sexual relations. It should be noted that the intestate estate (if any) would devolve to the State in the event where there are no intestate beneficiaries present. ${ }^{113}$

\section{Intestate Succession Disqualifications and Substitution}

An intestate succession disqualification prevents an intestate beneficiary from inheriting due to certain attributes. The three types of intestate succession disqualifications looked at in this paper are divorce, adoption, and unworthiness. An affinity tie is severed subsequent to the dissolution of a marriage through divorce. A divorced spouse would not be deemed a surviving spouse for purposes of the Intestate Succession Act 81 of $1987 .{ }^{114}$ Spouses who were married in terms of Islamic law are recognised as spouses for purposes of the Intestate Succession Act 81 of $1987 .{ }^{115}$ A matter concerning an Islamic law irrevocable divorce in the form of a faskh was heard at the Western Cape High Court in Hassam v Jacobs NO and Others. ${ }^{116}$

A child would be disqualified from inheriting as an intestate beneficiary from his natural parents and vice versa in the event where an adoption order has been granted in favour of his or her adoptive parents. The exception to the disqualification would be where the natural parent is also the adoptive parent of the child or was married to the adoptive parent at the time the adoption

113 See s 92 of the Administration of Estates Act 66 of 1965. Islamic law has a similar provision in this regard. Islamic law requires the intestate estate be deposited into an Islamic public treasury.

114 See s 1 of the Intestate Succession Act 81 of 1987.

115 See Intestate Succession Act 81 of 1987. See also Daniels v Campbell NO \& Others 2004 (5) SA 331 (CC) para 40(1)(a)(i) where it was declared that 'the word "spouse" as used in the Intestate Succession Act 81 of 1987, includes the surviving partner to a monogamous Muslim marriage.' and Hassam v Jacobs NO \& Others 2009 (5) SA 572 (CC) para 47.3.1 where it was declared that 'section 1 of the Intestate Succession Act 81 of 1987 is inconsistent with the Constitution and invalid to the extent that it does not include more than one spouse in a polygynous Muslim marriage in the protection it affords to "a spouse".' A spouse subject to an Islamic irrevocable divorce would be disqualified from inheriting as an intestate beneficiary in terms of both Islamic law as well as South African law.

116 See Hassam v Jacobs NO \& Others 2009 (5) SA 572 (CC) para 6 where the court noted that '[t]he High Court, relying on the rule enunciated in Plascon-Evans Paints Ltd $v$ Van Riebeeck Paints (Pty) Ltd, found that the marriage was extant at the time of the deceased's death.' 
The Impact of the South African Law of Succession and Administration of Estates on South African Muslims

order was granted. The natural parent would then not be disqualified. ${ }^{117}$ An intestate beneficiary would be disqualified from inheriting as such if he or she is deemed to be an unworthy person. ${ }^{118}$ An example of unworthiness would be where an intestate beneficiary unlawfully killed the deceased. ${ }^{119} \mathrm{~A}$ disqualified intestate beneficiary would be deemed predeceased. The intestate benefit due to a disqualified intestate beneficiary would devolve in terms of the law of intestate succession. An example of this would be where $\mathrm{X}$ leaves behind an intestate estate of R300 000.00 and a widower, a disqualified son, and an agnate granddaughter who is the child of the disqualified son as the only intestate beneficiaries. The widower would inherit R250 000.00 and the agnate granddaughter would inherit the remaining R50 000.00. The same would apply if the son in the example was predeceased. ${ }^{120}$

\section{Intestate Succession Exclusions}

An intestate succession exclusion prevents an intestate beneficiary from inheriting in part or in full due to the presence of one or more other intestate

117 See s 1(4)(e) of the Intestate Succession Act 81 of 1987 where it states that 'an adopted child shall be deemed - ... (ii) not to be a descendant of his natural parent or parents, except in the case of a natural parent who is also the adoptive parent of that child or was, at the time of the adoption, married to the adoptive parent of the child.' De Waal MJ \& Schoeman-Malan, Law of Succession, 28.

118 See Paleker M., 'Capacity to Inherit,' 105-112.

119 De Waal MJ \& Schoeman-Malan, Law of Succession, 116-118. It should be noted that the killer in the example would also be disqualified in terms of the Islamic law of intestate succession.

120 This is in terms of s 1(7) of the Intestate Succession Act 81 of 1987 that states that '[i]f a person is disqualified from being an heir of the intestate estate of the deceased, or renounces his right to be such an heir, any benefit which he would have received if he had not been so disqualified or had not so renounced his right shall, subject to the provisions of subsection (6), devolve as if he had died immediately before the death of the testator and, if applicable, as if he was not so disqualified.' It should be noted that a disqualified intestate beneficiary is also regarded as predeceased in terms of Islamic law. The consequences of being deemed predeceased in terms Islamic law differ to the consequences of being predeceased in terms of South African law. The widower would inherit 1/4 x R300 $000.00=\mathrm{R} 75000.00$ as a sharer beneficiary; the agnate granddaughter would inherit $1 / 2=2 / 4 \times$ R150 000.00 as a sharer beneficiary; and the agnate daughter would also inherit the residue of $1 / 4 \times$ R300 $000.00=$ R75 000.00 as a return beneficiary. It can clearly be seen in this example that the Islamic law provisions are more favourable for the agnate granddaughter (female). 
beneficiaries. An example of a partial exclusion would be where $\mathrm{X}$ dies leaving behind an intestate estate of R300 000.00. She also leaves behind a widower and a daughter as the only intestate beneficiaries. The widower would inherit R250 000.00 and the daughter would inherit the remaining R50 000.00. The daughter is partially excluded by the widower. ${ }^{121}$ The daughter would have inherited the full R300 000.00 if the widower was not present. ${ }^{122}$ An example of total exclusion would be where X leaves behind an intestate estate of R300 000.00. She also leaves behind a widower and a mother as the only intestate

121 See s 1 of the Intestate Succession Act 81 of 1987 where it states that '(1) If after the commencement of this Act a person (hereinafter referred to as the "deceased") dies intestate, either wholly or in part, and - ... (c) is survived by a spouse as well as a descendant - (i)such spouse shall inherit a child's share of the intestate estate or so much of the intestate estate as does not exceed in value the amount fixed from time to time by the Minister of Justice by notice in the Gazette, whichever is the greater; and (ii) such descendant shall inherit the residue (if any) of the intestate estate.' The amount fixed by the Minister is currently R250 000.00. See 'Chief Master's Directive 3 of 2015, Circular 58 of 2015, effective 17 August 2015, www.justice.gov.za/master/m_docs/2015-03_chm-directive.pdf, accessed on 16 November 2017.

122 Partial exclusion would also apply to the above example in terms of Islamic law. The daughter would have inherited more favourably in terms of Islamic law. She would inherit $1 / 2=4 / 8 \times$ R300 $000.00=\mathrm{R} 150000.00$ as a sharer beneficiary. See Khan MM, The Noble Qur'an - English Translation of the Meanings and Commentary 1404H (4) 11 where it states 'Allah commands you as regards your children's (inheritance); to the male, a portion equal to that of two females; if (there are) only daughters, two or more, their share is two thirds of the inheritance; if only one, her share is half; but if they leave a child, you get a fourth of that which they leave after payment of legacies that they may have bequeathed or debts.' The widower would inherit $1 / 4=2 / 8 \times$ R300 $000.00=\mathrm{R} 75000.00$ as a sharer beneficiary. See Khan MM, The Noble Qur'an - English Translation of the Meanings and Commentary 1404H (4) 12 where it states '[i]n that which your wives leave, your share is a half if they have no child.' The daughter would also inherit the remaining 2/8 x R300 $000.00=\mathrm{R} 75000.00$ as a doctrine of return beneficiary It should be noted that the daughter would inherit three times more than the widower. It can be seen that Islamic law clearly favours the daughter (female) over the widower (male) in this example. 
The Impact of the South African Law of Succession and Administration of Estates on South African Muslims

beneficiaries. The widower would inherit the R300 000.00 and the mother would not inherit. The widower totally excludes the mother from inheriting. ${ }^{123}$

\section{Intestate Succession Limitations}

There are no direct limitations that apply to the law of intestate succession. There are, however, some indirect limitations. The law of intestate succession would apply only in the event where the liability claims and testate succession claims have not depleted the gross estate. ${ }^{124}$ This means that liability claims and testate succession claims take priority over intestate succession claims. ${ }^{125}$ Intestate beneficiaries could be referred to as optional beneficiaries as they can be disinherited through testacy. ${ }^{126}$

123 See s 1 of the Intestate Succession Act 81 of 1987 where it states that '(1) If after the commencement of this Act a person (hereinafter referred to as the "deceased") dies intestate, either wholly or in part, and - (a) is survived by a spouse, but not by a descendant, such spouse shall inherit the intestate estate.' It should be noted that the widower would not totally exclude the mother in terms of Islamic law. The widower would inherit $1 / 2=6 / 12 \times \mathrm{R} 300000.00=\mathrm{R} 150000.00$ as a sharer beneficiary. See Khan MM, The Noble Qur'an - English Translation of the Meanings and Commentary 14004H (4) 12 where it states '[i]n that which your wives leave, your share is a half if they have no child...' The mother would inherit 4/12 x R300 000.00 = R100 000.00 as a sharer beneficiary. See Khan MM, The Noble Qur'an - English Translation of the Meanings and Commentary 1404H 4 (11) where it states that '.. . [f]or parents, a sixth share of inheritance to each if the deceased left children; if no children, and the parents are the (only) heirs, the mother has a third; if the deceased left brothers or (sisters), the mother has a sixth.' The mother would inherit the remaining $1 / 3=2 / 12 \times \mathrm{R} 300000.00=\mathrm{R} 50000.00$ as a doctrine of return beneficiary. The mother and widower inherit equal amounts in this example. It is interesting to note that the mother (female) in this example inherits more favourably in terms of Islamic law than in terms of South African law.

124 See De Waal MJ \& Schoemann-Malan MC, Law of Succession 5 ed (2015) 14-15.

125 It is interesting to note that the Islamic law position is similar in this regard. Liability claims and testate succession claims take priority over intestate succession claims. The Islamic law liability claims are not exactly the same as those found in terms of South African law.

126 The Islamic law position is quite different as these intestate beneficiaries can be referred to as compulsory beneficiaries. They can only be disinherited through testacy if the inheriting intestate beneficiaries consent thereto. 


\section{Intestate Succession Adiation, Repudiation, Substitution and Collation}

An intestate beneficiary has the option to either adiate (accept) or to repudiate (reject) the benefit. The repudiated benefit could devolve to a substitute beneficiary or could devolve in terms of the law of intestate succession depending on which intestate beneficiary repudiates. ${ }^{127}$ An intestate beneficiary acquires an enforceable right to the intestate benefit upon adiation thereof. Adiation must take place subsequent to the testator or testatrix having died. This moment is also referred to as "dies cedit". ${ }^{128}$ There is a presumption in favour of adiation. The presumption is rebutted by repudiation. ${ }^{129}$.

Section 1(6) of the Intestate Succession Act 81 of 1987 states that '[i]f a descendant of a deceased, excluding a minor or mentally ill descendant, who, together with the surviving spouse of the deceased, is entitled to a benefit from an intestate estate renounces his right to receive such a benefit, such benefit shall vest in the surviving spouse. ${ }^{130}$ It could be said that the surviving spouse would substitute the repudiating descendant. Section 1(7) of the Intestate Succession Act 81 of 1987 states that '[i]f a person is disqualified from being

127 An example of how repudiation would affect the distribution is where a deceased leaves behind an intestate estate of R300 000.00. He also leaves behind a mother, a widow, and a child who is neither a minor nor mentally ill and repudiates as the only intestate beneficiary. The widow would totally exclude the mother from inheriting. She would inherit R250 000.00 as a surviving spouse and the remaining R50 000.00 as a substitute for the child who repudiated the benefit. See s 1 of the Intestate Succession Act 81 of 1987 where it states that '(1) If after the commencement of this Act a person (hereinafter referred to as the "deceased") dies intestate, either wholly or in part, and - ... (c) is survived by a spouse as well as a descendant - (i)such spouse shall inherit a child's share of the intestate estate or so much of the intestate estate as does not exceed in value the amount fixed from time to time by the Minister of Justice by notice in the Gazette, whichever is the greater; and (ii)such descendant shall inherit the residue (if any) of the intestate estate.' read with s 1(6) of the Intestate Succession Act 81 of 1987 where it states that ' $[i] f$ a descendant of a deceased, excluding a minor or mentally ill descendant, who, together with the surviving spouse of the deceased, is entitled to a benefit from an intestate estate renounces his right to receive such a benefit, such benefit shall vest in the surviving spouse.'

128 Rautenbach C, 'Introduction,' 12-16.

129 See De Waal MJ \& Schoemann-Malan MC, Law of Succession 4 ed (2008) 193. It should be noted that adiation of an intestate benefit is not required in terms of Islamic law. The intestate benefit would automatically devolve in terms of the general laws of intestate succession.

130 See s 1(6) of the Intestate Succession Act 81 of 1987. 
The Impact of the South African Law of Succession and Administration of Estates on South African Muslims

an heir of the intestate estate of the deceased, or renounces his right to be such an heir, any benefit which he would have received if he had not been so disqualified or had not so renounced his right shall, subject to the provisions of subsection (6), devolve as if he had died immediately before the death of the testator and, if applicable, as if he was not so disqualified.' ${ }^{131}$

The doctrine of collation states that the value of all gifts given to certain intestate heirs prior to the death of the deceased must be subtracted from his or her intestate estate. The doctrine of collation would apply only if it is called for by a person entitled to do so. ${ }^{132}$ An example of how the doctrine applies would be where X dies leaving behind an intestate estate of R3 000000.00 . He also leaves behind a son and daughter as his only intestate beneficiaries. His daughter is an admitted attorney and has recently started her own law firm. X gave his daughter R500 000.00 in order to start a law firm. The amount was given to her one month prior to $\mathrm{X}$ having died. The son and daughter would inherit R1 500000.00 each if collation is not called for. The R500 000.00 would be included in the intestate estate calculation if the son calls for collation to take place. The son would then inherit R1 750000.00 and the daughter would inherit R1 250000.00 as she had already received R500 000.00 one month prior to $\mathrm{X}$ having died. ${ }^{133}$

\section{Classes of Intestate Beneficiaries and their Shares}

There are five classes of intestate beneficiaries who are eligible to inherit from the intestate estate. The order of priority regarding these classes is: spouses, descendants, parents, descendants of parents, and the nearest blood relatives other than those in the preceding four classes. ${ }^{134}$ The intestate estate would devolve to the Guardian's Fund in the event where there are no persons within

131 See s 1(7) of the Intestate Succession Act 81 of 1987.

132 Collation does not apply to legatees as they inherit under a particular title. See Wood-Bodley M, 'Collation,' in The Law of Succession in South Africa, ed. Juanita J. \& Rautenbach C. (Cape Town: Oxford, 2009), 193.

133 See Wood-Bodley M, 'Collation,' 193. It should be noted that the doctrine does not apply in terms of Islamic law of intestate succession.

134 See Intestate Succession Act 81 of 1987. 
the five classes present. ${ }^{135}$ There are nine rules that govern the distribution of the intestate estate in terms of South African law. ${ }^{136}$ These rules are now looked at by way of examples.

135 See s 25(13) of the Administration of Estates Act 66 of 1965 where it states that ' $[\mathrm{t}$ ] he executor shall not later than two months after the estate has become distributable in terms of subsection (12), pay to the Master for deposit in the Guardian's Fund on behalf of the persons entitled thereto, all moneys which he has for any reason been unable to distribute in accordance with the account.' See also s 92 of the Administration of Estates Act 66 of 1965 where it states that '[a]ny money in the Guardian's Fund (whether such money has been paid into the said fund before or after the commencement of this Act) which has remained unclaimed by the person entitled thereto for a period of thirty years as from the date upon which such person became entitled to claim the said money, shall be forfeited to the State.' It should be noted that a similar provision is found in terms of Islamic law where the intestate estate would devolve to an Islamic public treasury. The mode of administration would however differ in terms of the two legal systems.

136 See $\mathrm{s} 1$ of the Intestate Succession Act 81 of 1987 where it states that '(1) If after the commencement of this Act a person (hereinafter referred to as the "deceased") dies intestate, either wholly or in part, and - (a) is survived by a spouse, but not by a descendant, such spouse shall inherit the intestate estate; (b) is survived by a descendant, but not by a spouse, such descendant shall inherit the intestate estate; (c) is survived by a spouse as well as a descendant - (i) such spouse shall inherit a child's share of the intestate estate or so much of the intestate estate as does not exceed in value the amount fixed from time to time by the Minister of Justice by notice in the Gazette, whichever is the greater; and (ii) such descendant shall inherit the residue (if any) of the intestate estate; (d) is not survived by a spouse or descendant, but is survived (i) by both his parents, his parents shall inherit the intestate estate in equal shares; or (ii) by one of his parents, the surviving parent shall inherit one half of the intestate estate and the descendants of the deceased parent the other half, and if there are no such descendants who have survived the deceased, the surviving parent shall inherit the intestate estate; or (e) is not survived by a spouse or descendant or parent, but is survived (i) by (aa) descendants of his deceased mother who are related to the deceased through her only, as well as by descendants of his deceased father who are related to the deceased through him only; or (bb) descendants of his deceased parents who are related to the deceased through both such parents; or (cc) any of the descendants mentioned in subparagraph (aa), as well as by any of the descendants mentioned in subparagraph (bb), the intestate estate shall be divided into two equal shares and the descendants related to the deceased through the deceased mother shall inherit one half of the estate and the descendants related to the deceased through the deceased father shall inherit the other half of the estate; or (ii) only by descendants of one of the deceased parents of the deceased who are related to the deceased through such parent alone, such descendants shall inherit the intestate estate; (f) is 
The Impact of the South African Law of Succession and Administration of Estates on South African Muslims

Rule number one states that the spouse or spouses of a deceased person would inherit the intestate estate in the event where a deceased leaves behind a spouse or spouses, but where there are no descendants present. ${ }^{137}$ An example of rule number one would be where $\mathrm{X}$ dies leaving behind an intestate estate of R150 000.00. She also leaves behind a widower, a mother, a father, and two daughters as the only intestate beneficiaries. The widower would inherit the entire R150 000.00 in terms of s 1(1)(a) of the Intestate Succession Act 81 of 1987 to the exclusion of the mother and father. ${ }^{138}$ It should be noted that the definition of a surviving spouse has been extended to include surviving spouses to de facto monogamous marriages as well as polygynous marriages that were contracted in terms of Islamic law. ${ }^{139}$

not survived by a spouse, descendant, parent, or a descendant of a parent, the other blood relation or blood relations of the deceased who are related to him nearest in degree shall inherit the intestate estate in equal shares.'

137 S 1(1) of the Intestate Succession Act 81 of 1987 where it states that '(1) If after the commencement of this Act a person (hereinafter referred to as the "deceased") dies intestate, either wholly or in part, and - (a) is survived by a spouse, but not by a descendant, such spouse shall inherit the intestate estate.' See also Hassam $v$ Jacobs NO \& Others 2009 (5) SA 572 (CC) where it was held that the section applies to surviving spouses in polygynous marriages.

138 See s 1(1)(a) of the Intestate Succession Act 81 of 1987.

139 See Daniels v Campbell NO \& Others 2004 (5) SA 331 (CC); and Hassam v Jacobs NO \& Others 2009 (5) SA 572 (CC) where it was held that the section applies to surviving spouses in monogamous and polygynous Islamic law marriages. The distribution of the abovementioned example would be different in terms of Islamic law. The widower would inherit $1 / 2=3 / 6 \times$ R600 $000.00=$ R300 000.00; the mother would inherit 1/6 x R600 $000.00=\mathrm{R} 100000.00$ and the father would inherit $2 / 6$ x R600 $000.00=$ R200 000.00. See Khan MM, The Noble Qur'an - English Translation of the Meanings and Commentary 1404H (4) 12 where it states '[i]n that which your wives leave, your share is a half if they have no child...' It should also be noted that there is a minority opinion within Islamic law that the mother should inherit $1 / 3=2 / 6 \times \mathrm{R} 600000.00=\mathrm{R} 200000.00$; and the father should inherit 1/6 x R600 $000.00=$ R100 000.00 in this example. See Khan MM, The Noble Qur'an - English Translation of the Meanings and Commentary 1404H (4) 11 where it states '... [f]or parents, a sixth share of inheritance to each if the deceased left children; if no children, and the parents are the (only) heirs, the mother has a third; if the deceased left brothers or (sisters), the mother has a sixth. A more detailed discussion on this issue is beyond the scope of this paper. It can clearly be seen that Islamic law distributes the intestate estate to a larger number intestate beneficiaries than South African law. 
Rule number two states that the descendant or descendants of a deceased person would inherit the intestate estate in the event where a deceased is survived by one or more descendants, but where there is no spouse present. ${ }^{140}$ An example of rule number two would be where $X$ dies leaving behind an intestate estate of R180 000.00. He also leaves behind a son, a daughter, a mother, and a father as the only intestate beneficiaries. The son would inherit R90 000.00 and the daughter would inherit R90 000.00. The mother and father would be totally excluded from inheriting from the intestate estate. ${ }^{141}$ It should be noted that the definition of a descendant also includes a son or daughter born out of a marriage concluded in terms of Islamic law.

Rule number three states that each spouse would inherit R250 000.00 or a child's share, ${ }^{142}$ whichever is the greater, and the child or children would inherit the remainder of the intestate estate, in the event where a deceased leaves

140 See $\mathrm{s} 1$ of the Intestate Succession Act 81 of 1987 where it states that '(1) If after the commencement of this Act a person (hereinafter referred to as the 'deceased') dies intestate, either wholly or in part, and - ... (b) is survived by a descendant, but not by a spouse, such descendant shall inherit the intestate estate.'

141 The share that each descendant would inherit would not always be the same in Islamic law. The distribution of the intestate estate in the above example would be different in terms of Islamic law. The mother would inherit $1 / 6=3 / 18 \times \mathrm{R} 180$ $000.00=\mathrm{R} 30$ 000.00; the father would inherit $1 / 6=3 / 18 \times \mathrm{R} 180000.00=\mathrm{R} 30$ 000.00; and the son and daughter would share the remainder. See Khan MM, The Noble Qur'an - English Translation of the Meanings and Commentary 1404H (4) 11 where it states that '... [f] or parents, a sixth share of inheritance to each if the deceased left children.' and Khan MM, The Noble Qur'an - English Translation of the Meanings and Commentary 1404H (4) 11 where it states that 'Allah commands you as regards your children's (inheritance); to the male, a portion equal to that of two females.' The son would inherit double the share of the daughter. The son would inherit 8/18 x R180 $000.00=\mathrm{R} 80$ 000.00; and the daughter would inherit $4 / 18 \times \mathrm{R} 180000.00=\mathrm{R} 40000.00$. It is interesting to note that the mother and father inherit equal shares in this example. The son, however, inherits double the share of the daughter.

142 See s 1(4) of the Intestate Succession Act 81 of 1987 where it states that '[i]n the application of this section - ... (f) a child's portion, in relation to the intestate estate of the deceased, shall be calculated by dividing the monetary value of the estate by a number equal to the number of children of the deceased who have either survived him or have died before him but are survived by their descendants, plus the number of spouses and women referred to in paragraphs (a), (b) and (c) of section 2(2) of the Reform of Customary Law of Succession and Related Matters Act, 2008.' 
The Impact of the South African Law of Succession and Administration of Estates on South African Muslims

behind a spouse or spouses, including one or more descendants. ${ }^{143}$ An example of rule number three would be where $\mathrm{X}$ dies leaving behind an intestate estate of R150 000.00. She also leaves behind a widower, a mother, a father, and two daughters as the only intestate beneficiaries. The widower would inherit the entire R150 000.00 to the exclusion of the mother, father, and the two daughters. In Islamic law marriages, spouses and the children born from these marriages are also eligible to inherit in terms of this rule. The widower is the only inheriting intestate beneficiary in this example. ${ }^{144}$

143 See s 1(1) of the Intestate Succession Act 81 of 1987 where it states that '[i]f after the commencement of this Act a person (hereinafter referred to as the 'deceased') dies intestate, either wholly or in part, and - ... (c) is survived by a spouse as well as a descendant - (i) such spouse shall inherit a child's share of the intestate estate or so much of the intestate estate as does not exceed in value the amount fixed from time to time by the Minister of Justice by notice in the Gazette, whichever is the greater; and (ii) such descendant shall inherit the residue (if any) of the intestate estate.' The amount fixed by the Minister is currently R250 000.00. See 'Chief Master's Directive 3 of 2015, Circular 58 of 2015, effective 17 August 2015, available at www.justice.gov.za/master/m_docs/2015-03_chm-directive. pdf, accessed 16 November 2017.

144 It should be noted that the parents, children, and spouses in the example would inherit collectively with the widower in terms of Islamic law. The widower would inherit $1 / 4=3 / 12$; the mother would inherit $1 / 6=2 / 12$; the father would inherit $1 / 6=2 / 12$; and the two daughters would equally share $2 / 3=8 / 12$. The doctrine of increase would apply in this example as the fractions add up to more than one unit. The new denominator would be 15 . The widower would inherit $3 / 15 \times$ R150 $000.00=\mathrm{R} 30000.00$, the mother would inherit $2 / 15 \times \mathrm{R} 150000.00=\mathrm{R} 20000.00$, the father would inherit $2 / 15 \times \mathrm{R} 150000.00=\mathrm{R} 20000.00$, and the two daughters would share the $8 / 15 \times \mathrm{R} 150000.00=\mathrm{R} 80000.00$. Each daughter would inherit R40 000.00. It can clearly be seen in this example that the females inherit the bulk of the intestate estate, and that the mother and father inherit equal shares. See Khan MM, The Noble Qur'an - English Translation of the Meanings and Commentary $1404 \mathrm{H}$ (4) 11 where it states that '[i]n that which your wives leave, your share is a half if they have no child.', Khan MM, The Noble Qur'an - English Translation of the Meanings and Commentary 1404H (4) 11 where it states that '... [f]or parents, a sixth share of inheritance to each if the deceased left children; if no children, and the parents are the (only) heirs, the mother has a third; if the deceased left brothers or (sisters), the mother has a sixth.' Khan MM, The Noble Qur'an - English Translation of the Meanings and Commentary 1404H (4) 11 where it states that '... [f] or parents, a sixth share of inheritance to each if the deceased left children; if no children, and the parents are the (only) heirs, the mother has a third; if the deceased left brothers or (sisters), the mother has a sixth.' Khan MM, The Noble Qur'an - English Translation of the Meanings and Commentary 1404H (4) 11 where it states that 'Allah commands you as regards your children's (inheritance); to the male, a portion equal to that of two females; if (there are) only daughters, two or more, their share is two thirds of the inheritance.' 
Rule number four states that the parents would inherit the intestate estate in equal shares in the event where a deceased leaves behind no spouse or descendant, but leaves behind both parents. ${ }^{145}$ An example of rule number four would be where X leaves behind an intestate estate of R300 000.00. He also leaves behind a mother and a father as the only intestate beneficiaries. The mother would inherit R150 000.00 and the father would inherit R150 000.00. ${ }^{146}$

Rule number five states that the surviving parent would inherit $1 / 2$ of the intestate estate and the descendants of the predeceased parent would inherit the remaining $1 / 2$ in the event where a deceased leaves behind no spouse and no descendants, but leaves behind one parent, and the predeceased parent leaves behind descendants. ${ }^{147}$ An example of rule number five would be where X dies leaving behind an intestate estate of R600 000.00. He also leaves behind a mother and a consanguine brother as the only intestate beneficiaries. The

145 See s 1 of the Intestate Succession Act 81 of 1987 where it states that '(1) If after the commencement of this Act a person (hereinafter referred to as the 'deceased') dies intestate, either wholly or in part, and - ... (d) is not survived by a spouse or descendant, but is survived - (i) by both his parents, his parents shall inherit the intestate estate in equal shares.'

146 A different distribution would apply in terms of Islamic law. The mother would inherit $1 / 3 \times \mathrm{R} 300000.00=\mathrm{R} 100000.00$; and the father would inherit the remainder which is 2/3 x R300 $000.00=$ R200 000.00. See Khan MM, The Noble Qur'an - English Translation of the Meanings and Commentary 1404H (4) 11 where it states that '... [f] por parents, a sixth share of inheritance to each if the deceased left children; if no children, and the parents are the (only) heirs, the mother has a third; if the deceased left brothers or (sisters), the mother has a sixth.', and Khan MM The Translation of the Meanings of Sahih Al Bukhari vol 8 (724) 477 where it states that ' $[\mathrm{t}]$ he Prophet said, "Give the Fara'id (the shares of the inheritance that are prescribed in the Qur'an) to those who are entitled to receive it. Then whatever remains, should be given to the closest male relative of the deceased". It can clearly be seen that the father inherits double the share of the mother.

147 See s 1(1) of the Intestate Succession Act 81 of 1987 where it states that '[i]f after the commencement of this Act a person (hereinafter referred to as the 'deceased') dies intestate, either wholly or in part, and -... (d) is not survived by a spouse or descendant, but is survived - ... (ii) by one of his parents, the surviving parent shall inherit one half of the intestate estate and the descendants of the deceased parent the other half.' 
The Impact of the South African Law of Succession and Administration of Estates on South African Muslims

mother would inherit 1/2 x R600 $000.00=\mathrm{R} 300000.00$ and the consanguine brother would inherit $1 / 2 \times \mathrm{R} 600000.00=\mathrm{R} 300000.00 .{ }^{148}$

Rule number six states that the surviving parent would inherit the entire intestate estate in the event where the deceased leaves behind no spouse or descendants, but leaves behind one surviving parent, while the predeceased parent did not leave behind any descendants. ${ }^{149}$ An example of rule number six would be where, for example, $\mathrm{X}$ dies leaving behind an intestate estate of R500 000.00. He also leaves behind a father and a consanguine sister as the only intestate beneficiaries. The father would inherit the entire R500 000.00 and the consanguine sister would be totally excluded by the father. ${ }^{150}$

148 A different distribution would apply in terms of Islamic law. The mother would inherit 1/3 x R600 $000.00=\mathrm{R} 200$ 000.00; and the consanguine brother would inherit the remainder which is $2 / 3$ x R600 $000.00=\mathrm{R} 400$ 000.00. See Khan MM, The Noble Qur'an - English Translation of the Meanings and Commentary 1404H (4) 11 where it states that '... [f]or parents, a sixth share of inheritance to each if the deceased left children; if no children, and the parents are the (only) heirs, the mother has a third.', and See Khan MM, The Noble Qur'an - English Translation of the Meanings and Commentary (4) 176 where it states that 'They ask you for a legal verdict. Say: "Allah directs (thus) about al-kalālah (those who leave neither descendants nor ascendants as heirs). If it is a man that dies, leaving a sister, but no child, she shall have half the inheritance. If (such a deceased was) a woman, who left no child, her brother takes her inheritance.' See also Khan MM The Translation of the Meanings of Sahih Al Bukhari 1391H (724) vol 8, 477 where it states that '[t]he Prophet said, "Give the Fara'id (the shares of the inheritance that are prescribed in the Qur'an) to those who are entitled to receive it. Then whatever remains, should be given to the closest male relative of the deceased."'.

149 See s 1(1) of the Intestate Succession Act 81 of 1987 where it states that '[i]f after the commencement of this Act a person (hereinafter referred to as the 'deceased') dies intestate, either wholly or in part, and - ... (d) is not survived by a spouse or descendant, but is survived- (ii) by one of his parents, the surviving parent shall inherit one half of the intestate estate and the descendants of the deceased parent the other half, and if there are no such descendants who have survived the deceased, the surviving parent shall inherit the intestate estate.'

150 It is interesting to note that the same distribution would apply in terms of Islamic law as far as this example is concerned. The father would inherit the complete intestate estate of R500 000.00 in his capacity of being the only residuary beneficiary. See Khan MM The Translation of the Meanings of Sahih Al Bukhari $1391 \mathrm{H}$ (724) vol 8, 477 where it states that '[ $\mathrm{t}$ ]he Prophet said, "Give the Fara'id (the shares of the inheritance that are prescribed in the Qur'an) to those who are entitled to receive it. Then whatever remains, should be given to the closest male relative of the deceased.", 
Rule number seven states that the intestate estate must be split up into two equal parts in the event where the deceased leaves behind no spouse, no descendants, and no parents, but leaves behind descendants of both predeceased parents. One half of the intestate estate must be distributed between the descendants related to the deceased through the predeceased mother and the remaining $1 / 2$ must be distributed between the descendants related to the deceased through the predeceased father. ${ }^{151}$ An example of rule number seven would be where X dies leaving behind an intestate estate of R400 000.00. He also leaves behind a uterine brother and a consanguine sister as the only intestate beneficiaries. The uterine brother would inherit R200 000.00 and the consanguine sister would inherit R200 000.00. . $^{152}$

Rule number eight states that the one or more descendants of a predeceased parent would inherit the entire intestate estate in the event where the deceased leaves behind no spouses, no descendants, and no parents, but leaves behind

151 See s 1(1) of the Intestate Succession Act 81 of 1987 where it states that '[i]f after the commencement of this Act a person (hereinafter referred to as the 'deceased') dies intestate, either wholly or in part, and - ... (e) is not survived by a spouse or descendant or parent, but is survived-(i) by-(aa) descendants of his deceased mother who are related to the deceased through her only, as well as by descendants of his deceased father who are related to the deceased through him only; or (bb) descendants of his deceased parents who are related to the deceased through both such parents; or (cc) any of the descendants mentioned in subparagraph (aa), as well as by any of the descendants mentioned in subparagraph (bb), the intestate estate shall be divided into two equal shares and the descendants related to the deceased through the deceased mother shall inherit one half of the estate and the descendants related to the deceased through the deceased father shall inherit the other half of the estate.'

152 It should be noted that a different distribution would apply in terms of Islamic law. The uterine brother would inherit 1/6; and the consanguine sister would inherit $1 / 2=3 / 6$. The doctrine of return would apply. The new denominator would be four. The uterine brother would inherit $1 / 4 \times \mathrm{R} 400000.00=\mathrm{R} 100000.00$ and the consanguine sister would inherit R300 000.00. It is interesting to note that the female in this example would inherit more favourably in terms of Islamic law than in terms of South African law. See Khan MM, The Noble Qur'an English Translation of the Meanings and Commentary 1404H (4) 12 where it states that '...[i]f the man or woman whose inheritance is in question has left neither ascendants nor descendants, but has left a brother or a sister, each one of the two gets a sixth...' Khan MM, The Noble Qur'an - English Translation of the Meanings and Commentary 1404H (4) 176 where it states that '[t]hey ask you for a legal verdict. Say: "Allah directs (thus) about al-kalālah (those who leave neither descendants nor ascendants as heirs). If it is a man that dies, leaving a sister, but no child, she shall have half the inheritance...' 
The Impact of the South African Law of Succession and Administration of Estates on South African Muslims

one or more descendants of one predeceased parent only. ${ }^{153}$ An example of rule number eight would be where a deceased leaves behind an intestate estate of R500 000.00. He also leaves behind a consanguine sister as the only intestate beneficiary. The consanguine sister would inherit the R500 000.00. ${ }^{154}$

Rule number nine states that nearest blood relation to the deceased would inherit the intestate estate in the event where the deceased leaves behind no spouse, or descendants, or parents, or descendants of his parents. ${ }^{155}$ An example of this would be where a deceased leaves behind an intestate estate of R500 000.00. He also leaves behind a paternal grandfather as the only intestate beneficiary. The paternal grandfather would inherit the R500 000.00. ${ }^{156}$

153 See s 1(1) of the Intestate Succession Act 81 of 1987 where it states that '[i]f after the commencement of this Act a person (hereinafter referred to as the 'deceased') dies intestate, either wholly or in part, and - ...(e) is not survived by a spouse or descendant or parent, but is survived - ... (ii) only by descendants of one of the deceased parents of the deceased who are related to the deceased through such parent alone, such descendants shall inherit the intestate estate'

154 It should be noted that the same distribution would apply in terms of Islamic law as far as this example is concerned. The consanguine sister would inherit $1 / 2 \mathrm{x}$ R500 $000.00=\mathrm{R} 250000.00$ as a sharer beneficiary; and the residue of R250 000.00 as a doctrine of return beneficiary. See Khan MM, The Noble Qur'an English Translation of the Meanings and Commentary 1404H (4) 176 where it states that '[t]hey ask you for a legal verdict. Say: "Allah directs (thus) about alkalälah (those who leave neither descendants nor ascendants as heirs). If it is a man that dies, leaving a sister, but no child, she shall have half the inheritance..."

155 See s 1(1) of the Intestate Succession Act 81 of 1987 where it states that '[i]f after the commencement of this Act a person (hereinafter referred to as the 'deceased') dies intestate, either wholly or in part, and - ... (f) is not survived by a spouse, descendant, parent, or a descendant of a parent, the other blood relation or blood relations of the deceased who are related to him nearest in degree shall inherit the intestate estate in equal shares.'

156 It is interesting to note that the same distribution would apply in terms of Islamic law. The paternal grandfather would inherit the R500 000.00 as a residuary beneficiary. See Khan MM The Translation of the Meanings of Sahih Al Bukhari $1391 \mathrm{H}(724)$ vol 8, 477 where it states that '[t]he Prophet [PBUH] said, "Give the Fara'id (the shares of the inheritance that are prescribed in the Qur'an) to those who are entitled to receive it. Then whatever remains, should be given to the closest male relative of the deceased." 


\section{Position of Females within the Law of Intestate Succession}

This position of females within the South African law of intestate beneficiaries in terms of the Intestate Succession Act 81 of 1987 is now looked at. ${ }^{157}$ The South African law of intestate succession is generally gender-neutral. Males and females would inherit equal shares. This is now shown by looking at a few examples.

A surviving spouse would inherit the entire intestate estate in the event where $\mathrm{X}$ dies leaving behind an intestate estate of R100 000.00, a surviving spouse, and a mother as the only intestate beneficiaries. This is in terms of $\mathrm{s}$ 1(1)(a) of the Intestate Succession Act 81 of $1987 .{ }^{158}$ The provision is genderneutral and the surviving spouse would inherit the R100 000.00 irrespective of whether it is a widow or widower.

A surviving descendant would inherit the entire intestate estate in the event where X dies leaving behind an intestate estate of R100 000.00, a surviving descendant, and a mother as the only intestate beneficiaries. This is in terms of s 1(1)(b) of the Intestate Succession Act 81 of $1987 .{ }^{159}$ The provision is gender-neutral and the surviving descendant would inherit the R100 000.00 irrespective of whether it is a son or daughter.

A surviving parent would inherit the entire intestate estate in the event where $\mathrm{X}$ dies leaving behind an intestate estate of R100 000.00, a surviving parent, and a full brother of father as the only intestate beneficiaries. This is in terms of $s 1(1)(d)\left(\right.$ ii) of the Intestate Succession Act 81 of $1987 .{ }^{160}$ The

157 See Intestate Succession Act 81 of 1987.

158 See s 1(1) of the Intestate Succession Act 81 of 1987 where it states that '[i]f after the commencement of this Act a person (hereinafter referred to as the "deceased") dies intestate, either wholly or in part, and - (a) is survived by a spouse, but not by a descendant, such spouse shall inherit the intestate estate.'

159 See s 1(1) of the Intestate Succession Act 81 of 1987 where it states that '[i]f after the commencement of this Act a person (hereinafter referred to as the 'deceased') dies intestate, either wholly or in part, and - ... (b) is survived by a descendant, but not by a spouse, such descendant shall inherit the intestate estate.'

160 See s 1(1) of the Intestate Succession Act 81 of 1987 where it states that '[i]f after the commencement of this Act a person (hereinafter referred to as the 'deceased') dies intestate, either wholly or in part, and- ...(d) is not survived by a spouse or descendant, but is survived ... (ii) by one of his parents, the surviving parent shall inherit one half of the intestate estate and the descendants of the deceased parent the other half, and if there are no such descendants who have survived the deceased, the surviving parent shall inherit the intestate estate.' 
The Impact of the South African Law of Succession and Administration of Estates on South African Muslims

provision is gender-neutral and the surviving parent would inherit the R100 000.00 irrespective of whether it is a mother or father.

A descendant of a deceased parent would inherit the entire intestate estate in the event where X dies leaving behind an intestate estate of R100 000.00, a descendant of a deceased parent, and a full brother of father as the only intestate beneficiaries. This is in terms of s 1(1)(e)(ii) of the Intestate Succession Act 81 of $1987 .{ }^{161}$ The provision is gender-neutral and the surviving parent would inherit the R100 000.00 irrespective of whether it is a brother or sister.

\section{CONCLUSION}

This paper looked at the South African law of succession and administration of estates in general terms. It more specifically looked at the impact of these South African law provisions on administration of estates of South African Muslims. The findings show that the Islamic and South African laws of succession and administration of estates are quite different. The findings further show that Muslim marriages are recognised for certain aspects regarding South African succession law provisions. The recognition has however led to the application of South African law and not Islamic law distribution with regard to the estates of deceased Muslims in this regard. The findings have also shown that the South African common law right to freedom of testation can be used by South African Muslims in order to ensure that their estates are distributed according to Islamic law. I would encourage all South African Muslims to make use of this right in order to apply Islamic law to their estates upon their demise.

\section{REFERENCES}

Al-Munajjid MS, 'Adoption is of Two Types - Forbidden and Prescribed,' available at https://islamqa.info/en/10010, accessed on 28 October 2017.

Al-Munajjid MS, 'Is it Permissible to Put the Sperm of the Husband and the Egg from the Wife in the Womb of the Second Wife?' https://islamqa. info/en/83799, accessed on 28 October 2017.

161 See s 1 of the Intestate Succession Act 81 of 1987 where it states that '(1) If after the commencement of this Act a person (hereinafter referred to as the 'deceased') dies intestate, either wholly or in part, and - ...(e) is not survived by a spouse or descendant or parent, but is survived ... (ii) only by descendants of one of the deceased parents of the deceased who are related to the deceased through such parent alone, such descendants shall inherit the intestate estate.' 
BBC News, 'Mandla Mandela's Conversion to Islam Sparks South Africa: Disquiet,' available at http://www.bbc.com/news/worldafrica-35539541, accessed on 20 October 2017.

Boorhaanol, 'Cape Muslim Heritage at a Glance,' available at http://livingislam. co.za/index.php?option $=$ com_content $\& v i e w=$ article $\& i d=180$ :capemuslim-history-at-a-glance $\&$ catid $=87$ :history\&Itemid $=445, \quad$ accessed on 18 November 2017.

Bukhari A, Treatise on Inheritance in Islam (Madinah: Al Rasheed Printers, 2004).

'Chief Master's Directive 3 of 2015, Circular 58 of 2015, effective 17 August 2015,' available at www.justice.gov.za/master/m_docs/2015-03_chmdirective.pdf, accessed on 16 November 2017.

Compare Guru, 'Funerals in South Africa and what they Cost - Muslim Burial Culture,' available at http://compareguru.co.za/news/funeral-customsin-sa-and-what-they-cost/, accessed on 3 January 2017.

De Waal MJ \& Schoeman-Malan MC, Law of Succession (Cape Town: Juta, 2015).

Funeral Cover Quotes, 'Apart from Cultural Beliefs, Cost is a Big Factor in Deciding on Cremation,' available at http://funeral-cover-quotes. co.za/326/costs/cremation-high-funeral-cost, accessed on 27 June 2016.

Hartley U, 'The Cost of Death' http://www.vocfm.co.za/the-cost-of-death/, accessed on 18 June 2016.

Himonga C \& Nhlapo T (eds), African Customary Law in South Africa - Post Apartheid and Living Law Perspectives (Cape Town: Oxford, 2015).

Jamiatul Ulama Kwazulu Natal, 'Resolving a Community of Property Estate?' available at https://jamiat.org.za/resolving-a-community-of-propertyestate/, accessed on 21 October 2017.

Jamneck J., 'Freedom of Testation,' in The Law of Succession in South Africa, ed. Juanita J. \& Rautenbach C. (Cape Town: Oxford, 2009).

Khan MM, The Noble Qur'an - English Translation of the Meanings and Commentary (Madinah: King Fahd Complex for the Printing of the Holy Quraan, 1404H).

Kruger H \& Skelton A (eds), The Law of Persons in South Africa (Cape Town: Oxford, 2012). 
The Impact of the South African Law of Succession and Administration of Estates on South African Muslims

Mahida EM, History of Muslims in South Africa: A Chronology (Durban: Arabic Study Circle, 1993).

Mangxamba S, 'Stats SA meets Faith Based Organisations on Census 2011,' available at http://www.statssa.gov.za/?page_id=3970, accessed on 18 December 2017.

Mufti Muhammad Taqi Usmani, 'Entitlement to Death Benefits Payable by Pension Funds,' available at http://www.muftitaqiusmani.com/index. php?option $=$ com_content\&view $=$ article\&id $=54$ : entitlement-to-deathbenefits-payable-by-pension-funds\&catid=10: economics $\&$ Itemid $=17$, accessed on 11 January 2015.

Muslim Judicial Council (SA) Fatwa Committee, 'MJC Position on Succession Law and Related Matters,' (2017) document on file with the author of this thesis. This document (fatwa) was issued based on a number of questions that I referred to the Muslim Judicial Council Fatwaa Department during 2017.

Omar MS, The Islamic Law of Succession and its Application in South Africa (Durban: Butterworths, 1988).

Paleker M, 'Intestate Succession,' in The Law of Succession in South Africa, ed. Juanita J. \& Rautenbach C. (Cape Town: Oxford, 2009).

Paleker M., 'Capacity to Inherit,' in The Law of Succession in South Africa, ed. Juanita J. \& Rautenbach C. (Cape Town: Oxford, 2009), 99-114.

Rautenbach C, 'A Few Comments on the (Possible) Revival of the Customary Law Rule of Male Primogeniture: Can the Common-Law Principle of Freedom of Testation come to its Rescue?' in South African Law of Succession and Trusts: The Past Meeting the Present and Thoughts for the Future, ed. Waal N \& Paleker M (Claremont: Juta, 2014).

Rautenbach C, 'Administration of Estates' in The Law of Succession in South Africa, ed. Juanita J. \& Rautenbach C. (Cape Town: Oxford, 2009).

Rautenbach C, 'Introduction' in The Law of Succession in South Africa, ed. Juanita J. \& Rautenbach C. (Cape Town: Oxford, 2009).

Rautenbach C, Gokul R, Bernhard BN \& Goolam MM, 'Law of Succession,' in Introduction to Legal Pluralism in South Africa. Part II Religious Legal Systems, ed. Rautenbach C \& Goolam NMI (Durban: Butterworths, 2002).

Skelton A \& Carnelley M (eds), Family Law in South Africa (Cape Town: Oxford, 2014). 
Statistics South Africa, 'Census 2001 Primary Tables South Africa 96 and 2001 Compared,' available at http://www.statssa.gov.za/census01/html/ RSAPrimary.pdf, accessed on 3 January 2015.

Traditional Council, 'Mvezo Komkhlu,' available at http://www. mvezotraditionalcouncil.org.za/the-chief, accessed on 20 October 2017.

Van Der Linder A, 'Content of Wills - Substitution, Usufruct, and Accrual,' in The Law of Succession in South Africa, ed. Juanita J. \& Rautenbach C. (Cape Town: Oxford, 2009).

Wood-Bodley M, 'Collation,' in The Law of Succession in South Africa, ed. Juanita J. \& Rautenbach C. (Cape Town: Oxford, 2009).

Wood-Bodley M, 'Formalities for a Will,' in The Law of Succession in South Africa, ed. Juanita J. \& Rautenbach C. (Cape Town: Oxford, 2009).

Al-Zuḥaylī, W., al-Fiqh al-Islāmī wa Adillatuh, 3rd ed. (Damascus: Dār alFikr, 1989).

\section{Statutes}

Administration of Estates Act 66 of 1965.

Child Care Act 74 of 1983.

Children's Act 38 of 2005.

Constitution of the Republic of South Africa, 1996.

Estate Duty Act 4 of 1955.

Intestate Succession Act 81 of 1987.

Law of Succession Amendment Act 43 of 1992.

Maintenance of Surviving Spouses Act 27 of 1990.

Marriage Act 25 of 1961.

Matrimonial Property Act 88 of 1984.

Pension Funds Act 24 of 1956.

Prescription Act 68 of 1969.

Reform of Customary Law of Succession and of Related Matters Act 11 of 2009. 


\section{Cases}

Bhe and Others $v$ Magistrate Khayelitsha and Others 2005 (1) SA 580 (CC).

Curators, Emma Smith Educational Fund v University of KwaZulu-Natal 2010

(6) SA 518 (SCA).

Daniels v Campbell NO \& Others 2004 (5) SA 331 (CC).

Duplan v Loubser 2015 ZAGPPHC 849.

Gory v Kolver 2007 (4) SA 97 (CC).

Hassam v Jacobs NO \& Others 2008 (4) All SA 350 (C).

Hassam $v$ Jacobs NO \& Others 2009 (5) SA 572 (CC).

Moosa NO and Others $v$ Harnaker and Others 2017 (6) SA 425 (WCC). 
Jurnal Syariah, Jil. 27, Bil. 2 (2019) 321-366 